\title{
O Processo Penal no estado de Santa Catarina entre Primeira República e Era Vargas
}

\author{
The Criminal Procedure in the State of Santa Catarina \\ between the First Republic and the Vargas Era
}

\author{
Diego Nunes ${ }^{1}$ \\ Universidade Federal de Santa Catarina - Florianópolis/SC, Brasil \\ nunes.diego@ufsc.br \\ lattes.cnpq.br/7745448598386819 \\ orcid.org/0000-0003-4909-0564 \\ Bárbara Madruga da Cunha² \\ Universidade Federal de Santa Catarina - Florianópolis/SC, Brasil \\ bmadrugacunha@gmail.com \\ http://lattes.cnpq.br/3737910172415411 \\ https://orcid.org/0000-0003-2130-9704 \\ Mayessa H. Costa ${ }^{3}$ \\ Universidade Federal de Santa Catarina - Florianópolis/SC, Brasil \\ mayessahc@gmil.com \\ http://lattes.cnpq.br/4187509073378031 \\ https://orcid.org/0000-0002-3463-0794
}

1 Professor Adjunto de Teoria e História do Direito da UFSC. Doutor em Ciências Jurídicas, currículo História do Direito, pela Universidade de Macerata (Itália). Dedica seus estudos à história brasileira do penal, em especial relacionada à criminalidade política. Colíder do Grupo de Pesquisa em História da Cultura Jurídica "Ius Commune" da UFSC e integrante do Grupo de Pesquisa em História da Cultura Jurídica "Studium Iuris” da UFMG. Tutor do PET Direito UFSC. Membro do doutorado "Law and Innovation" da Universidade de Macerata (Itália).

2 Doutoranda em Direito pela UFSC, mestra em Teoria e História do Direito pela mesma instituição. Graduada em Direito pela UFPR. Dedica seus estudos à história brasileira do penal, em especial relacionada às mulheres. Integrante dos Grupos de Pesquisa em História da Cultura Jurídica "Ius Commune" da UFSC e do "Studium Iuris" da UFMG.

3 Mestra em Teoria e História do Direito pela UFSC. Graduada em Direito pela UNIVALI. Dedica seus estudos à história brasileira do penal, em especial relacionada aos animais. Integrante dos Grupos de Pesquisa em História da Cultura Jurídica “Ius Commune” da UFSC e Estudos e Saberes Ambientais da UFPB. 
Resumo: O trabalho tem como objetivo analisar a formação e desenvolvimento do processo criminal no Estado de Santa Catarina (Brasil) no período entre a Constituição Federal de 1891 e o Código de Processo Penal de 1941, em que os estados federados possuíam a competência legislativa sobre direito processual. Para tanto, analisou-se a legislação, partindo do Código de Processo Criminal de 1832, que vigeu até a elaboração do Código Judiciário catarinense de 1925, passando por suas reformas até a reunificação do direito processual penal pela codificação realizada pelo Estado Novo. Debruçou-se, também, sobre fontes jornalísticas e doutrinárias do período, para melhor contextualizar e compreender as opções legislativas locais, além da historiografia sobre o tema. Como resultados, notou-se a relativa indiferença do estado de Santa Catarina sobre a legislação processual penal durante a maior parte da Primeira República, mesmo durante crises políticas que abalaram o Judiciário de Santa Catarina. Mas, na parte final deste período, foram confeccionadas duas codificações estaduais e uma lei de reforma, com destaque para a paulatina restrição à competência do Tribunal do Júri como regra nos processos-crime, ainda que essa fosse mais ampla do que a presente no código estadonovista.

Palavras-Chave: História do Direito; Justiça Criminal; Codificação; Federalismo; Santa Catarina (Brasil).

ABSTRACT: This article aims to analyze the formation and development of criminal procedure in the State of Santa Catarina (Brazil) between the Federal Constitution of 1891 and the Code of Criminal Procedure of 1941, when the states had the legislative competence on procedural law. For this, we analyzed the legislation, departing from the Code of Criminal Procedure of 1832, enforced up to the elaboration of the Catarinense Judiciary Code of 1925 , passing through its reforms until the reunification of criminal procedural law by the codification enacted by the Estado Novo regime. We analyzed journalistic and academic sources from that time as well, to better contextualize and understand the local legislative options, besides historiographical literature on the subject. As results, we noted the relative indifference by the State of Santa Catarina about the criminal procedural legislation during a major part of the First Republic, even in political crises that the Santa Catarina Judiciary suffered. However, in the final part of this period two codifications and a reform act were made, which progressively restricted the number of crimes judged by jury, even if there were still more than the present number of the Estado Novo's code. 
KeYwords: Legal History; Criminal Justice; Codification of law; Federalism; State of Santa Catarina (Brazil).

SuMÁRıo: Introdução; 1. O processo penal em Santa Catarina durante a Primeira República; 2. O processo penal em Santa Catarina nos anos 1930; 3. A unificação nacional do processo penal; Conclusões; Referências.

\section{INTRODUÇÃO}

Durante a Primeira República, com o advento do sistema federalista, o qual foi trazido pela Constituição Federal de 1891, a competência para legislar em matéria processual restou aos Estados. Interessante notar que se tratava de uma competência tácita, pois a União resguardou para si apenas "legislar sobre o direito civil, comercial e criminal da República e o processual da Justiça Federal" ". As constituições de 1891 e 1895 do Estado de Santa Catarina, cuja realidade será aprofundada neste texto, também não fazem menção específica à matéria ${ }^{5}$.

Assim, antes do Código Processo Penal de 1941, que mesmo repleto de modificações ainda se encontra em vigor, é possível constatar a descentralização das normas processuais penais, as quais eram caracterizadas por diferenças locais que influenciavam a aplicação das leis. Neste sentido, Alfredo Flores e Régis Nodari ${ }^{6}$ alertaram, ao realizarem uma pesquisa sobre a elaboração do Código de Processo Penal de 1898 do Estado do Rio Grande do Sul, que a análise das leis processuais penais exige um estudo sociopolítico de cada ente federado, tendo em vista as

4 BRASIL. Constituição da República dos Estados Unidos do Brasil. Prudente José de Mores Barros, Presidente do Congresso. Rio de Janeiro, fev. 1891, art. 34, n. 23.

5 A CONSTITUIÇÃO Federal e as constituições dos estados da república do Brazil. V. I-II. Pelotas: Livraria Universal, 1895-1896.

6 FLORES, Alfredo de Jesus Dal Molin; NODARI, Régis João. Entrelaçamentos Culturais na Primeira República: O código de processo penal dos Estado do Rio Grande do Sul (1898) e suas fontes doutrinárias e legislativas. Revista da Faculdade de Direito de Minas Gerais, Belo Horizonte, n. 74, p. 65-96, 2019. 
peculiaridades do regime jurídico dos Estados, os quais possuíam arranjos institucionais próprios. A partir dos anos 1930, entretanto, a mudança de regime e certas exigências da vida em sociedade, bem como mudanças no mundo do direito, convergiram para que a matéria fosse unificada com o retorno a um código unitário.

Saliente-se que ao tempo do Império o Brasil contou com um Código de Processo Criminal desde 1832. Sua principal característica era a prevalência do júri como forma de estabelecimento dos veredictos. Este passou por importantes reformas em 1841 e 1871 que justamente mitigavam o caráter acusatório e negocial, com a exclusão do juiz de paz e o advento do delegado de polícia e a criação do inquérito policial, respectivamente. Pode-se dizer que foi se passando de uma maneira participativa para uma forma burocrática de administração da justiça ${ }^{7}$.

Tendo em vista a escassez de estudos relacionados ao processo penal durante a Primeira República, em especial no caso catarinense, o presente artigo tem o objetivo de apresentar um quadro geral da matéria processual penal e as modificações por ela sofridas durante a Primeira República e a Era Vargas, até a publicação do Código de Processo Penal de 1941. Para isso, uma ampla pesquisa documental foi realizada, incluindo os códigos de organização judiciária de Santa Catarina, relatórios emitidos pelos governadores do Estado e documentos jornalísticos, além do Código de Processo Penal de 1941, inclusa sua exposição de motivos.

A seleção e análise das fontes, ademais, orientou-se pela concepção de Pietro Costa, para quem é preciso perceber os fatos "através da mediação da cultura, da linguagem, do saber próprios do ambiente histórico e da

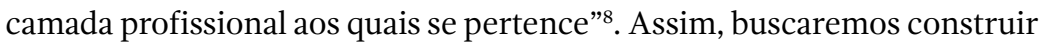
uma narrativa histórica que considere tanto os aparatos jurídicos (normas, técnicas e procedimentos) quanto os discursos (presentes nos comentários dos juristas, em textos jornalísticos, etc.). Conforme elucida Costa, "estudar os aparatos da justiça significa apreender, ao mesmo tempo, o

7 NUNES, Diego. Codificação, Recodificação, Descodificação? Uma História das dimensões jurídicas da justiça no Brasil Imperial a partir do Código de Processo Criminal de 1832. Revista da Faculdade de Direito de Minas Gerais, Belo Horizonte, n. 74, p. 135-166, 2019.

8 COSTA, Pietro, Em busca de textos jurídicos: quais textos para qual historiador?. In: ID., Soberania, representação, democracia. Curitiba: Juruá, 2010. p. 20. 
funcionamento intrínseco e as modalidades de seu enxerto na organização geral dos poderes" ${ }^{10}$. Se debruçar nos discursos, por sua vez, é buscar analisar as imagens, teorias e representações do objeto que se propõe a estudar. Nesse sentido, o autor alerta que é preciso ter em conta a distinção entre textos de conhecimento, orientados para a representação "desinteressada" do objeto, e textos diretamente envolvidos na práxis, orientados para a "decisão", ou seja, a torção "partidária” de uma argumentação proativa e a formulação de princípios "universalistas" na oratória "interessada"11.

A partir da metodologia proposta por Costa ${ }^{12}$, buscaremos compreender os aspectos jurídicos da história da justiça em Santa Catarina, tensionando os aparatos jurídicos relativos ao processo penal com alguns discursos produzidos sobre eles, procurando sempre contextualizar socialmente a representação dos mesmos.

Para isso, trataremos inicialmente do início da Primeira República no contexto do Estado de Santa Catarina, analisando os códigos judiciários locais, os quais possuíam normas de direito processual penal. Em seguida, explicaremos como as modificações no regime político do país repercutiram na organização judiciária e no processo penal catarinense. Por fim, falaremos brevemente sobre a organização do Código de Processo Penal de 1941, analisando suas modificações em relação à matéria.

\section{O processo penal em Santa Catarina durante a Primeira REPÚBLICA}

O Estado de Santa Catarina nunca chegou a constituir um código de processo penal propriamente dito. Nos primeiros anos da República, optou-se por manter a aplicação do Código de Processo Criminal do

9 No original, "Studiare gli apparati di giustizia significa coglierne, al contempo, l'intrinseco funzionamento e le modalità del loro innesto nella complessiva organizzazione dei poteri” (COSTA, op. cit., 2010, p. 21).

10 COSTA, Pietro. Di che cosa fa storia della giustizia? Qualche considerazione di método. In: LACCHÈ, Luigi; MECCARELLI; Massimo (a cura di). Storia dell giustizia e storia del diritto: Prospetive europee di ricerca. Macerata: eum, 2012. p. 21.

11 Ibidem, p. 33.

12 COSTA, op. cit., 2010; 2012. 
Império, estabelecendo algumas normas complementares ${ }^{13}$. Já ao fim da Primeira República, o Estado organizou suas próprias normas processuais penais, integrou-as no Código Judiciário, o qual sistematizava a organização judiciária estatal, bem como a matéria processual civil e, a partir de então, penal.

O primeiro Código Judiciário Catarinense data de 1925, portanto, trinta e cinco anos depois do início do novo regime. A mora para a organização das normas processuais estatais, ao menos nos primeiros anos da República, pode ser explicada pela grande instabilidade política e jurídica que o Estado de Santa Catarina vivenciou. Em novembro de 1891 com a Primeira Revolta da Armada, Marechal Floriano Peixoto assumiu a presidência, depondo Deodoro da Fonseca. O então governador catarinense, Lauro Müller, era apoiador de Deodoro e por isso também foi afastado do cargo pelos "federalistas". O Estado passou a ser chefiado por uma junta governativa, para a qual havia grande resistência popular, formando-se grupos "republicanos" em defesa do antigo governador ${ }^{14}$.

Diante de conflitos políticos ${ }^{15}$, o Superior Tribunal de Justiça estadual (art. 47 da Constituição estadual de 1891) foi dissolvido pelo governo em 1893. Sob influência da Revolução Federalista iniciada no Rio Grande do Sul, os "republicanos” reagiram organizando tentativas de deposição do poder central, que culminaram na tomada do Palácio do Governo em 31 de julho daquele mesmo ano ${ }^{16}$. Com o fracasso da tentativa de destituição de Floriano Peixoto na capital do país, o Presidente

13 D'AQUINO, Ivo. Parecer da Comissão Especial. In: SANTA CATARINA. Lei $\mathrm{n}^{\circ}$ n. 1526, de 14 de novembro de 1925. Codigo Judiciario do Estado de Santa Catarina. Florianópolis: Officinas A Elect. da Imprensa Official, 1926.

14 VIEIRA, João Alfredo Medeiros. Notas para a história do poder judiciário em Santa Catarina. Florianópolis: Fundação Catarinense de Cultura, 1981.

15 Hercílio Luz, que representava os republicanos, agrediu um juiz de direito da comarca de Blumenau que, em resposta, abriu um processo-crime contra o ele. Luz foi pronunciado em primeira instância, mas ao apelar da sentença, o caso subiu para o Superior Tribunal de Justiça do estado, que decidiu em favor dos acusados (VIEIRA, op. cit.). Em razão dessa decisão, o tribunal foi dissolvido em abril de 1893, de modo que, dois dias depois, o Governador constituiu o Tribunal da Relação, nomeando novos desembargadores. O Superior Tribunal de Justiça do estado retornou com o art. 47 da Constituição estadual de 1895.

16 VIEIRA, op. cit., p. 155. 
da República, conhecido como "Marechal de Ferro", enviou tropas para Santa Catarina com a missão de reprimir os "republicanos". Logo que os conflitos cessaram, Hercílio Luz, importante político catarinense, foi eleito governador em 1894, cargo que ocupou por três mandatos ${ }^{17}$, representando o Partido Republicano Catarinense, o qual venceu todas as eleições para o cargo até 1930, quando o partido foi tirado do poder pela nomeação de um interventor federal da Aliança Federal pelo governo de Getúlio Vargas.

Mesmo com a progressiva estabilização do poder político estatal entre o final do século XIX e o começo do XX, o Código Judiciário só entrou em vigor em 1925, compilando e revisando leis esparsas já existentes acerca da organização judiciária e sobre matéria processual civil, além de prever normas de processo penal. Em setembro de 1911 foi publicada a Lei n. 919, a qual organizava o Poder Judiciário catarinense. Após sua entrada em vigor, contudo, seguiram mais de trinta leis revogando dispositivos ou adicionando normas àquela legislação. Segundo o Coronel Antônio Pereira da Silva e Oliveira ${ }^{18}$, governador em exercício do Estado em $1925^{19}$, as leis estatais não alteraram o processo criminal vigente até a publicação do primeiro código judiciário, de modo que até sua entrada em vigor aplicava-se o código processual de 1832, modificado pelas leis do Império ${ }^{20}$.

17 Relativos aos períodos de 1894 a 1898, 1918 a 1922 e 1922 a 1924 . Hercílio Luz não chegou a concluir seu último mandato, pois veio a falecer em outubro de 1924.

SILVA E OLIVEIRA, Antonio P. Mensagem apresentada ao Congresso Representativo, em 22 de julho de 1924, pelo Coronel Antonio Pereira da Silva e Oliveira, Vice-governador, no exercício do cargo de Governador do Estado de Santa Catharina.

19 Silva e Oliveira, na condição de vice, assumiu o posto principal, em outubro de 1924, em razão da morte de Pedro Hercílio Luz que até então ocupava o cargo de governador.

20 Nas palavras do governante, "releva ponderar que o processo criminal vigente no Estado, é o do Codigo de 1832, modificado pelas leis de 3 de dezembro de 1841 , de 20 de setembro de 1871 e pelos regulamentos n. ${ }^{\circ} 120$, de 31 de janeiro de 1842 , e n. ${ }^{\circ} 4824$, de 22 de novembro de 1871 , e se applica ao processo, julgamento e execução das causas civeis e commerciaes o regulamento n. ${ }^{\circ} 737$, de 25 de novembro de 1850" (SILVA E OLIVEIRA, op. cit., p. 11). 
A mora da organização de normas processuais próprias, contudo, não foi exclusividade catarinense. Entre os vinte e um Estados que compunham a Federação, apenas o Rio Grande do Sul elaborou um código de processo penal no final do século XIX ${ }^{21}$. Outros três legislaram sobre a matéria entre 1910 e 1914, e os demais só publicaram suas leis e códigos processuais entre 1918 e 1926. Para Sabadell ${ }^{22}$, esses dados seriam demonstrativos da falta de interesse por parte dos Estados em legislar sobre a matéria.

O Parecer da Comissão Especial encarregada de revisar o Código Judiciário de Santa Catarina de 1925 corrobora o argumento de Sabadell. Nele, o deputado relator Ivo D’Aquino sugeria que a ausência de codificação era propícia aos interesses do poder legislativo estadual. Segundo ele, tratava-se de um "amontoado desharmonico de leis esparsas, contradictorias e extravagantes que todos os annos o Congresso votava ao sabor, muitas vezes, das emergências e, não raro, de interesses pessoais" ${ }^{23}$.

Outro fator que pode explicar a demora dos Estados em organizarem suas normas processuais e judiciárias estava na ausência de clareza quanto às competências legislativas estatais. Conforme já anunciamos, ainda que a Constituição da República de 1891 tenha consagrado o sistema republicano federativo, ela apenas estabeleceu expressamente as atribuições privativas do Congresso Nacional, deixando de definir as

${ }^{21}$ A elaboração do Código de Processo Penal do Rio Grande do Sul também foi iniciada com uma lei de organização judiciária, a qual previa a complementação por meio de legislação processual (NODARI, FLORES, op. Cit.) e suas fontes doutrinárias e legislativas. Revista da Faculdade de Direito de Minas Gerais, Belo Horizonte, n. 74, p. 65-96, jan./jun. 2019). Para além do pioneirismo, Flores e Nodari apontaram que o Código de Processo Penal do Rio Grande do Sul era repleto de particularidades em relação a outros diplomas processuais, inclusive àqueles elaborados posteriormente por outros entes federativos.

SABADELL, A. L. Los Problemas del derecho procesal penal único en una federación: la experiencia de Brasil. In: Instituto Nacional de Ciencias Penales; Max-Planck Institut fuer Auslaendisches und Internationales Strafrecht. (Org.). Hacia la Unificación del Derecho Penal. Logros y desafíos de armonización y homologación en México y en el Mundo. Districto Federal- México: Instituto Nacional de ciencias Penales-INACIPE, 2006, v. 1, p. 585-615.

D’AQUINO, op. cit., p. 3. 
atribuições estaduais. Tampouco as constituições catarinenses, para o caso em estudo, anunciavam tal prerrogativa. Assim, a interpretação de que os Estados tinham competência para legislar em matéria processual se deu por exclusão, a partir da regra dos poderes remanescentes, ou seja, todas as competências que não fossem proibidas pela Constituição poderiam ser exercidas pelos entes federativos ${ }^{24}$.

Essa interpretação, entretanto, não era unânime. Segundo o parecer de Ivo D'Aquino ${ }^{25}$, havia juristas que defendiam a unidade processual pois esta permitiria a uniformidade da jurisprudência, facilitando a atividade profissional do advogado. Como era de se esperar, a comissão encarregada do Código Judiciário do Estado era contrária a esse posicionamento. O parecer se utilizava de argumentos deterministas para afirmar a necessidade de um código catarinense diverso dos demais Estados, visto que a legislação deveria se orientar pelas particularidades sociais e econômicas, bem como as condições físicas, a que cada unidade federativa estava condicionada:

Em contrario á unidade de processo, ergue-se a razão de que é impossivel legislar com cabal efficiencia, sob os mesmos moldes, para todos os Estados do Brasil, cuja disparidade de território, de vias de transporte, de população, de desenvolvimento economico e de condições physicas e sociaes em geral - jamais lograria acommodar-se com êxito a uma só systematização ${ }^{26}$.

O parecer ainda aponta que, apesar da comissão entender pela exclusividade da competência estatal em legislar em matéria processual, a doutrina de maior prestígio defendia que a competência era simultânea, tendo prioridade o poder central ${ }^{27}$. Por essa razão, o Código Judiciário de 1925 teria reproduzido normas que já estavam estatuídas em leis federais ${ }^{28}$.

Outro argumento que explica a demora do estado na disposição de normas processuais próprias foi encontrado em uma mensagem do

\footnotetext{
24 SABADELL, op. cit.

25 D'AQUINO, op. cit.

26 Ibidem, p. 4.

27 Ibidem.

28 Ibidem, p. 7.
} 
governador Felipe Schmidt, apresentada ao Congresso Representativo catarinense em 1900. Nela o governante defendia que o direito processual estatal só fosse codificado após a aprovação do Código Civil e a reforma do Código Penal de 1890, sob pena dos códigos processuais estaduais se tornarem inúteis, na medida em que eram normas adjetivas àquelas de direito material:

Não sou da opinião dos que aconselham cuidar-se quanto antes da codificação das nossas leis adjetivas: porque, penso, este trabalho correrá o risco de inutilidade desde que sejam approvados, como se espera, os projectos de Codigo Civil, já confeccionado, e o da reforma do Código Penal, já apresentado ${ }^{29}$.

Schmidt ${ }^{30}$ se referia ao projeto de código civil apresentado por Clóvis Beviláqua naquele mesmo ano e ao projeto de reforma do Código Penal de 1890 de autoria de João Vieira de Araújo, que à época estava em discussão na Câmara dos Deputados ${ }^{31}$. A codificação civil foi concluída em 1916, enquanto o direito penal só ganhou um novo código em 1940, apesar das diversas tentativas de reforma ${ }^{32}$. A mora dos trâmites para aprovação dos projetos apresentados parece consistir, portanto, em mais um fator capaz de explicar o longo período no qual Santa Catarina deixou de compilar suas normas processuais.

O projeto do Código Judiciário de 1925 ficou a encargo do desembargador Heraclito Carneiro Ribeiro ${ }^{33}$, nomeado pelo governo estadual. Depois de aprovado, contudo, vigorou por menos de três anos, sendo substituído em 1928 por uma nova codificação. Quanto à organização judiciária, não há diferenças significativas entre um código e outro,

29 SCHMIDT, Felippe. Mensagem apresentada ao Congresso Representativo. Em 11 de Agosto de 1900 pelo Dr. Felippe Schmidt, Governador do Estado. p. 12-13.

30

31

32

33

3 Juiz de Florianópolis, era filho de um importante médico e intelectual negro brasileiro, Ernesto Carneiro Ribeiro, um dos revisores do Projeto de Código Civil apresentado por Clóvis Beviláqua. 
havendo, de modo geral, apenas alteração de algumas nomenclaturas ${ }^{34}$. Ambos previam a existência do Ministério Público, o qual era composto por promotores públicos (um para cada comarca) e seus adjuntos, sendo chefiado pelo procurador geral do Estado. Os dois cargos eram nomeados pelo governador, que também escolhia os desembargadores do Superior Tribunal de Justiça a partir de uma lista de juízes de direito feita pelo próprio órgão. Os juízes de direito deveriam ser diplomados em ciências jurídicas ${ }^{35}$ e habilitados em concurso pelo Superior Tribunal de Justiça, o qual realizava uma lista tríplice, a qual era encaminhada ao governador, que detinha a decisão final. Os suplentes dos juízes de direito também eram nomeados pelo governador, o qual deveria escolher "dentre os cidadãos domiciliados e residentes na comarca, reconhecidamente probos e capazes, devendo ser preferidos os graduados em direito" (art. 37 do Código Judiciário de 1928) ${ }^{36}$. Por fim, havia os juízes de paz ou juízes distritais (na redação do Código Judiciário de 1928), os quais eram cidadãos eleitos pelos distritos. Para assumir o cargo, deveriam estar no gozo dos direitos políticos ou apresentar os requisitos para tanto, ser domiciliados no distrito e saber ler e escrever português. A relação entre o Judiciário e o Executivo era, portanto, bastante próxima, sendo o primeiro subordinado ao segundo, na medida em que o governador elegia os nomes para os principais cargos, sendo apenas os juízes dos distritos eleitos pelos cidadãos que usufruíam de direitos políticos.

Ambos os códigos ainda previam de forma quase idêntica a organização do júri, o qual era composto, para além do juiz de direito e do promotor público, por 28 jurados $^{37}$, sendo sete sorteados para compor o Conselho de Sentença. Para ser jurado era preciso saber ler e escrever português, estar no gozo dos direitos políticos, ser cidadão entre

34 Para dar um exemplo, o código de 1925 referia-se a "Governador do Estado" e "juiz de paz", enquanto o de 1928 substituía essas expressões por "Presidente do Estado" e "juiz distrital", respectivamente.

35 O código de 1925 referia-se a "sciencias jurídicas e sociaes" (art. 31), enquanto o de 1928 falava apenas em "sciencias juridicas" (art. 26).

36 O artigo 43 do código de 1925 apresentava redação praticamente idêntica, trocando a expressão "reconhecidamente probos e capazes" por "de reconhecida moralidade e aptidão".

37 O número legal para abertura da sessão, entretanto, era de vinte e um jurados (art. 83 do CJSC/1925 e art. 77 do CJSC/1928). 
vinte e um e sessenta anos, bem como ter rendimento anual mínimo de 2:400\$000, cuja prova era dispensada para os profissionais liberais. Entre as causas que impediam uma pessoa de ser jurada estava a notória "falta de bom senso, integridade e bons costumes" (art. 54, I do Código Judiciário de 1925) ${ }^{38}$. O “creado de servir" (art. 54, VIII do Código Judiciário de 1925) ${ }^{39}$ também estava impedido de desempenhar tal função. Tais disposições demonstram a importância da moralidade pública na sociedade catarinense e a tentativa de manutenção da sua estratificação socioeconômica pela elite jurídica.

A principal razão para a substituição do código de 1925 estava na reforma das normas processuais penais, sobretudo quanto à atribuição de competências do júri, a qual dependia da elaboração de um novo código judiciário. Segundo o governador Adolpho Konder, corroborando o argumento do Presidente do Superior Tribunal de Justiça do Estado:

Com evidente prejuízo para o interesse da Justiça, estão sendo julgados pelos tribunaes populares crimes, que, por sua natureza e qualidade das pessoas que os praticam, deviam recahir sob a competência de juizes singulares ou tribunaes especiaes. Taes são, entre outros, os delictos praticados por menores, os de fallencia fraudulenta ou culposa, os de injuria e calumnia, e os peculiares aos officiaes e praças da Força Publica ${ }^{40}$.

De fato, as constituições estaduais de 1891 e 1895 já limitavam o júri para os "crimes mais graves" ${ }^{41}$. Por certo, tratava-se de cláusula aberta e uma simples leitura do código penal de $1890^{42}$ não seria capaz de fechar a questão. Uma comparação com o decreto organizador da

38 O artigo 48, I, do código de 1928 reproduziu a redação de forma idêntica.

39 O artigo 48, IV, do código de 1928 se utiliza da mesma expressão.

40 KONDER, Adolpho. Mensagem apresentada á Assembléa Legislativa, a 29 de julho de 1929, pelo doutor Adolpho Konder, Presidente do Estado de Santa Catharina. p. 42.

41 Conforme o art. 55 de ambos os textos, “Art. 55. O Tribunal do Jury continúa a ter competência para julgar os crimes mais graves, com sua actual organização e na fórma da legislação em vigor, emquanto não revogada”.

42 BRASIL. Decreto $n^{\circ} 847$, de 11 de outubro de 1890: Promulga o Codigo penal. Rio de Janeiro, 1890a. 
justiça federal ${ }^{43}$ também não: todos os crimes de competência da União originalmente eram de competência do júri ${ }^{44}$. Posteriormente, o rol foi aclarado $^{45}$ e alguns crimes (como peculato, contrabando e moeda falsa ${ }^{46}$ passaram ao juiz singular.

Ainda, se analisada a doutrina da época, percebe-se que a primazia do júri era princípio geral consolidado:

Poucas são as violações da lei penal que escapam à competência do jury; e é certo que este, apesar de ter sido constitucionalmente creado também para questões civis, nunca funccionou sinão para

43 BRASIL. Decreto $n^{\circ}$ 848, de 11 de outubro de 1890: Organiza a Justiça Federal. Rio de Janeiro, 1890b.

${ }^{4}$ "Art. 40. Os crimes sujeitos á jurisdicção federal serão julgados pelo Jury" (BRASIL, 1890).

45 "Art. 83. Compete ao Jury federal julgar: a) os crimes politicos, e como taes se consideram os definidos no livro 2o, tit. 10 e seus capitulos, e tit. 2o, cap. 1o do Codigo Penal; b) a sedição contra funccionario federal ou contra a execução de actos e ordens emanadas de legitima autoridade federal, conforme a definição do art. 118 do Codigo Penal; c) a resistencia, desacato e desobediencia á autoridade federal e tirada de presos do poder da justiça federal, segundo as disposições dos capitulos 3 a 5 do tit. 20 do citado livro do Codigo Penal; d) os crimes de responsabilidade dos funccionarios federaes que não tiverem fôro privilegiado (Tit. 5 do cit. livro), não comprehendido o de peculato; e) os crimes contra a propriedade nacional comprehendidos no cap. 10 do tit. 12 do mesmo livro; f) a falsificação de actos das autoridades federaes, de titulos da divida nacional, de papeis de credito e de valores da nação ou de banco autorisado pelo Governo Federal; não comprehendidos os definidos nos arts. 246, 247 e 250 do Codigo Penal; g) interceptação ou subtracção de correspondencia postal ou telegraphica do Governo Federal (Cap. 4o do Tit. 4o do mesmo livro); h) os crimes contra o livre exercicio dos direitos politicos nas eleições federaes ou por occasião de actos a ella relativos (Cap. 1o do Tit. 4o do mesmo livro); i) a falsidade de depoimento ou de outro genero de prova em Juizo federal (Secção 4a do Cap. 20 do Tit. 60 do mesmo livro); j) os crimos definidos no Tit. 3o, 1a parte da lei n. 35, de 26 de janeiro de 1892" (BRASIL, 1898a).

${ }_{46}$ "Art. $1^{\circ}$ Fica competindo ao juiz de Secção no Districto Federal e nos Estados da União o julgamento dos crimes de moeda falsa, contrabando, peculato, falsificação de estampilhas, sellos adhesivos, vales postaes e coupons de juros dos titulos da divida publica da União, qualificados nos arts. 221 a 223, 239 a $244,246,247$ e 265 do Codigo Penal e do uso de qualquer destes papeis e titulos falsificados, qualificados no art. 250 do mesmo Codigo" (BRASIL, 1898b). 
o julgamento de processos criminaes, havendo, mesmo, nesta materia, tendência para restringir suas attribuições ${ }^{47}$.

Mas, em julho de 1928, diante do contexto nacional ${ }^{48}$ e das reivindicações do Superior Tribunal de Justiça do Estado, um novo código judiciário foi publicado, restringindo as atribuições do júri. A regra geral, contudo, continuava sendo a de que os crimes eram julgados pelo tribunal popular e as competências dos juízes de direito eram manifestamente expressas no código judiciário ${ }^{49}$. Na prática, contudo, o júri estadual ficava

47 WHITACKER, Firmino. Jury (Estado de S. Paulo). São Paulo: Typ. Espíndola, Siqueira \& Comp., 1904, p. 10.

48 Veja-se, por exemplo, a limitação da competência do júri federal para o julgamento dos crimes cometidos por anarquistas a partir de 1921 (NUNES, Diego. Le "irrequietas leis de segurança nacional": sistema penale e repressione del dissenso politico nel Brasile dell'Estado Novo (1937-1945). Tese de Doutorado (Direito). Università degli studi di Macerata (Itália), 2014, p. 210-217).

Segundo o art. 181, inciso IX, do Código Judiciário de Santa Catarina de 1928, "Art. 181 - Compete ao juiz de direito, no crime: [...] IX - Processar e julgar: a) os crimes funccionaes do prefeito, do sub-prefeito, intendente e conselheiros municipaes; do juiz districtal, do promotor publico e seu adjuncto; de todos os empregados públicos que não tiverem fôro especial; b) os crimes previstos nos seguintes artigos do Codigo Penal e correspondentes leis modificadoras: 1 . - tirada ou fugida de presos do poder da justiça e arrombamento das cadeias (arts. 127 a 133). 2. - desacato e desobediência ás autoridades (arts. 134 e 135) e resistencia (arts. 124 a 126). 3. - incendio e outros crimes de perigo commum (arts. 136 a 148), resalvada a competencia da Justiça Federal no caso do art. 139. 4. - contra a segurança dos meios de transporte ou comunicação (arts. 149 a 154) quando não attribuidos por lei á Justiça Federal. 5. - contra a saude publica (paragr. unico do art. 156, § I, 2, do art. 157, paragr. unico do art. 158, arts. 160 a 164, e Decretos n. 4.294 de 6 de julho de 1921, n. 3.987 de 2 de janeiro de 1920 e n. 14.969 de 3 de setembro de 1921). 6. - carcere privado (arts. 181 a 183). 7. - contra a inviolabilidade do domicilio, no caso do paragr. unico do art. 196. 8. - falsidade de actos e documentos públicos e particulares (arts. 251 a 260 do Codigo Penal e Decreto n. 4.780, de 27 de dezembro de 1923). 9. - testemunho falso, declarações, queixas e denuncias falsas em juizo (arts. 261 a 264). 10. - violencia carnal, rapto, lenocinio e adulterio (arts. 266 a 281 do Codigo Penal, Lei n. 2.992 de 24 de setembro de 191[ilegível]). 11. Contra a segurança do estado civil (arts. 283 e 285 a 288). 12. - subtracção e ocultação de menores (arts. 289 a 292). 13. - calumnia e injuria (arts. 315, 316, 319 e 320 do Codigo Penal e Decreto n. 4.743 de 31 de outubro de 1923). 14. - damno (arts. 326 a 329). 15. - furto (arts. 330, paragr. 4 e 333) e apropriação indébita, qualquer que seja seu valor (arts. 331 a 332). 16. - fallencia (arts. 336 e 337 do Codigo Penal e Lei n. 2.024 de 17 de dezembro de 1908). 17. - estellionato 
mais restrito, devendo julgar apenas os crimes contra a vida: homicídio (art. 294 a 297), infanticídio (art. 298), indução ou auxílio ao suicídio (art. 299) e aborto (art. 300 a 302). O fato não passou desapercebido:

A competencia, no processo criminal, soffreu uma modificação profunda, acompanhando a corrente moderna de ampliar a Julgamento singular em prejuizo do Jury e do Tribunal Correccional que, nem aqui nem alhures, tem se imposto ao apreço publico como instrumentos idoneos de fazer Justiça [...] a enumeração dos crimes attribuidos á jurisdição do juiz singular é longa, ficando para o tribunal popular bem pouca coisa ${ }^{50}$.

A imprensa local não deixou de fazer o seu juízo sobre a questão:

Diante dessa farta enumeração, o que fizemos de proposito para conhecimento geral, ficará de parabens a actividade honesta, os elementos são da sociedade, que são, justamente, os que merecem toda a protecção dos poderes publicos, por isso que são os fatores de producção, riqueza e estabilidade social. A actividade deshonesta, attentatoria dos direitos alheios, não contará mais com a impunidade systematica do velho Jury, quer quanto as lesões moraes. A calumnia e a injuria passarão a ser punidas. O patrimonio moral dos cidadãos passará a ser respeitado. Julgamento de juiz singular, com recurso para o Superior Tribunal de Justiça, havemos forçosamente de iniciar uma phase de punição á delinquencia em suas variadas modalidades. E' obra de saneamento social o que se vem de fazer com o novo Codigo. $\mathrm{O}$ indice da criminalidade ha de baixar para bem da sociedade e para honra dos seus dirigentes [grifo nosso] ${ }^{51}$.

(arts. 338 a 340). 18. - contra a propriedade litteraria, artistica, industrial e commercial (arts. 342 a 355 do Codigo Penal, Lei n.496 de $1^{\circ}$ de agosto de 1898, Lei n. 1.236 de setembro de 1904). 19. - roubo (arts. 356 a 360). 20. fabricação ou porte de instrumentos proprios para roubar (art. 361). 21. - extorsões (art. 362). 22. - os crimes attentorios da ordem social (Lei n. 4269 de 17 de janeiro de 1921 , arts. $1^{\circ}$ a 11) quando não expressamente attribuidos á Justiça Federal. 23. - as contravenções em espécie (Livro III do Codigo Penal, excluidos os arts. 367, 368, 377, 378, 379 e 382, Lei n. 6.994 de 19 de junho de 1908, Lei n. 4.394 de 6 de julho de 1921)" (SANTA CATARINA, 1928). O NOVO CÓDIGO JUDICIARIO. República: Florianópolis, quinta-feira, $1^{\circ} \mathrm{de}$ novembro de 192., p. 2.

Ibidem. 
Nessa nova regulamentação, o processo criminal, em seu rito comum, iniciava-se a partir da abertura do inquérito policial ${ }^{52}$. Recebida a notícia crime ou em caso de flagrante delito, deveria a autoridade policial tomar todas as medidas necessárias para a coleta das provas, garantindo o estado de conservação das coisas, bem como interrogar as testemunhas e o acusado e solicitar a prisão preventiva, indicando as razões e provas para tanto.

O capítulo relativo ao inquérito policial do CJSC/1928 tinha como base o crime de homicídio. Assim, determinava que a autoridade policial deveria "photographar o cadaver na posição em que fôr encontrado, sempre que fôr possivel; appreenderá os instrumentos do crime e quaesquer objectos encontrados; colligirá os indicios existentes" ${ }^{53}$, bem como deveria proceder com o corpo delito, indicando dois profissionais peritos na matéria ${ }^{54}$.

Realizadas todas as diligências legalmente previstas, a autoridade policial era responsável por despachar os autos ao juiz respectivo, em caso de ação pública, e de entregá-los ao requerente quando a ação fosse privada. O prazo para conclusão e remissão do inquérito era de quinze dias, mas caso o acusado estivesse preso passava a ser de cinco dias a contar da data da prisão ${ }^{55}$.

Ao receber os autos, o juiz deveria encaminhá-los ao Ministério Público. Nas ações públicas, o promotor deveria oferecer a denúncia, podendo solicitar a realização de novas diligências ou o arquivamento do inquérito ${ }^{56}$, caso julgasse as provas insuficientes. Admitia-se como prova a confissão, o depoimento de testemunhas, o exame pericial, os documentos e os indícios ${ }^{57}$. A confissão só era

\footnotetext{
52 As exceções estavam previstas no artigo 2.055: "Não cabe inquerito: I - Nas infrações penaes de fôro privilegiado, II - Nos crimes de responsabilidade. III - Nos crimes militares. IV - Nas infrações penaes commetidas por menores de 18 annos" (SANTA CATARINA, op. cit., 1928, p. 351).

53 SANTA CATARINA. Lei ${ }^{\circ}$ n. 1640, de 03 de novembro de 1928. Codigo Judiciario do Estado de Santa Catarina, 1928, art. 2.042, I.

54 Ibidem, art. 2.042, II.

55 Vide artigos 2.044 e 2.045 do Código Judiciário de Santa Catarina de 1928.

56 Vide artigo 2.051 do referido Código Judiciário.

57 SANTA CATARINA, op. cit., art. 2.147.
} 
admitida se feita perante autoridade competente, versasse sobre o fato principal e coincidisse com as suas circunstâncias, bem como se fosse livre, espontânea e expressa ${ }^{58}$.

Em linhas gerais, as ações privadas eram relativas aos crimes de dano em domínio particular, corrupção de menores, violência carnal sem resultado morte ou dano grave à saúde, rapto, adultério, parto suposto, calúnia, injúria, lenocínio praticado pelo marido contra a esposa e crimes contra a propriedade intelectual ${ }^{59}$. Não eram admitidas queixas apresentadas contra cônjuge, pai, filho e irmão, assim como de advogado contra cliente, de relativamente incapaz sem representante legal e do inimigo capital $^{60}$. Mesmo nas ações públicas, o particular poderia apresentar queixa, cabendo ao Ministério Público promover a acusação, interpor recursos e assistir a parte em todos os julgamentos. Após o recebimento do inquérito, o promotor público tinha dez dias para se manifestar, sob

Ibidem, art. 2.148.

"Art. 2.096. - A denuncia compete ao Ministerio Publico em todas as infracções penaes, nos termos da legislação federal. Exceptuam-se os seguintes crimes: I - Damno [sic] em coisa de dominio particular, não tendo havido prisão em flagrante. II - Corrupção de menores, violencia carnal e rapto, salvo se a pessoa offendida fôr miseravel, ou asylada de algum estabelecimento de caridade; se da violencia carnal resultar morte, perigo de vida, ou alteração grave de saúde; se o crime fôr perpetrado com abuso de autoridade de pae, tutor, curador, preceptor ou amo. III - Adulterio e parto supposto. IV - Calumnia [sic] e injuria, salvo em se tratando de offensa a corporação que exerça autoridade publica, ou contra qualquer agente, ou depositário desta, em razão de suas funções. V - Crime do paragrapho único do art. 277 do Codigo Penal, quando praticado pelo marido contra a mulher, caso em que somente a esta cabe o direito de queixa. VI - Crime de furto, no caso do art. 335 do Codigo Penal, e observada a disposição do art. $1^{\circ}$ paragrapho unico da lei n. 628 , de 24 de outubro de 1899 . VII - Crimes contra a propriedade literária, artistica, industrial e commercial, salvo os casos expressos nas leis que protegem essas propriedades" (SANTA CATARINA, op. cit., 1928, p. 357).

"Art. 2.097. - Não se admite queixa ou representação: [...] Paragrapho único. E' inimigo capital de outro: I- Aquelle que contra elle teve, ou tem causa crime ou cível, sobre todos os bens, ou a maior parte delles. II - Aquelle que o feriu gravemente. III - Aquelle que lhe irrogou injuria, ou calumnia. IVAquelle contra elle commetteu furto, roubo, ou adulterio. V - O que praticou qualquer desses crimes contra o cônjuge, filho, neto, ou irmão daquelle, ou matou alguma dessas pessoas" (SANTA CATARINA, op. cit., 1928, p. 357). 
pena de multa. Nesse caso, o juiz deveria atuar ex officio, propondo a ação por meio de uma portaria ${ }^{61}$.

Recebida a denúncia pelo juiz, iniciava-se a formação de culpa, quando as partes eram citadas, o réu qualificado e as testemunhas intimadas para prestarem depoimento perante juízo ${ }^{62}$. Caso o réu não fosse representado por advogado particular, ele próprio era responsável por sua defesa. O código, entretanto, arrolava um rol taxativo ${ }^{63}$ de perguntas que poderiam ser feitas ao réu durante o interrogatório, o sumário de culpa e o plenário.

Como a regra geral prevista pelo código era de que os crimes deveriam ser julgados pelo júri, após a finalização do sumário de culpa o juiz deveria decidir pela pronúncia do acusado. Feita a pronúncia, o magistrado deveria abrir vistas ao Ministério Público que tinha três dias para oferecer o libelo acusatório ${ }^{64}$. Caso a ação fosse privada, o requerente deveria ser notificado para oferecer o documento em igual prazo.

Além do júri, o Código Judiciário de 1928 manteve a existência dos Tribunais Correcionais, que também podem ser considerados populares, uma vez que eram administrados pelas comunidades locais, através da figura do juiz distrital, eleito por voto censitário, e da participação de jurados no julgamento dos crimes de sua competência. O juiz distrital possuía o poder de formar a culpa e decidir pela submissão do réu a julgamento (art. 191, VI, do CJSC/1928), o qual era feito por dois "vogaes" sorteados entre aqueles que compunham a lista de jurados do

61 Vide artigo 2.108 do CJSC/1928.

${ }^{62}$ Vide artigos 2.172 e seguintes do CJSC/1928.

63 “Artigo 2.188. - No interrogatório, quer no summario, que no plenário, só poderá ser perguntado ao réo: I- Qual seu nome, naturalidade, idade, estado, filiação, residência e tempo della no lugar indicado. II - Quaes seus meios de vida e profissão. III - Se sabe ler e escrever. IV - Onde estava ao tempo em que se diz ter sido commetido o crime. $\mathrm{V}-\mathrm{Se}$ conhece as testemunhas arroladas, desde que tempo e se tem alguma coisa que lhes oppôr. VI - Se é verdade o que se alega na denuncia, ou queixa. VII - Se quer fazer alguma declaração, ou apresentar defesa oral, ou escripta [...] § $3^{\circ}$ - Não é permitido ao juiz, em caso algum, acrescentar perguntas ás mencionadas neste artigo; ao réo, entretanto, é licito alegar o que lhe convier, devendo ser escriptas todas as suas declarações" (SANTA CATARINA, op. cit., 1928 [grifos nossos]).

Vide artigo 2.205 do CJSC/1928. 
Tribunal do Júri e o próprio juiz distrital, que tinha direito a voto (art. 89 do CJSC/1928).

O Código Judiciário de 1928 ainda previa procedimentos distintos para o julgamento de menores ${ }^{65}$. Aqueles com menos de catorze anos não poderiam ser submetidos ao processo criminal, de forma que cabia a autoridade competente apenas registrar o ocorrido, avaliar o estado do menor e a "situação social, moral e economica dos paes" ${ }^{6}$. Já aqueles entre catorze e dezoito anos eram submetidos a um processo especial, no qual era suprimido o inquérito policial, e tinham direito a um defensor. Já os maiores de dezoito e menores de vinte e um anos deveriam ser assistidos por um curador ${ }^{67}$, mas respondiam ao rito processual comum.

As modalidades de recurso previstas no código eram: recurso em sentido estrito (art. 2.507), apelação (art. 2.528), protesto por novo julgamento (art.2.549), embargos (art. 2.554) e revisão (art. 2.558). O promotor público era obrigado a apelar no caso de sentença absolutória proferida pelos tribunais do júri e correcional quando a decisão fosse contrária a lei expressa, ou à prova dos autos, ou quando descumprisse formalidade substancial capaz de anular o processo ou o julgamento ${ }^{68}$. Já o juiz tinha a obrigação de apelar ex officio de todas as suas sentenças, salvo se elas fossem condenatórias ${ }^{69}$. Em caso de condenação, o código ainda previa a possibilidade de livramento condicional ${ }^{70}$.

O Código Judiciário de 1928 manteve-se vigente, em sua redação original, até meados da década de 1930. Com o início da Era Vargas, vários decretos estaduais modificaram algumas de suas disposições. Dentre eles, destaca-se o Decreto 20.348 de 1931, o qual será melhor analisado a seguir.

\footnotetext{
65 Vide artigo 2.329 e seguintes do CJSC/1928. 


\section{O processo penal em Santa Catarina nos anos 1930}

Nesse momento da história brasileira, Getúlio Vargas assumiu o poder em decorrência da chamada "Revolução de 1930", a qual destituiu Washington Luís e impossibilitou a posse de Júlio Prestes ao cargo de Presidente ${ }^{71}$. Com o golpe, os governadores estatais foram depostos e os chefes do Executivo passaram a ser interventores nomeados pelo poder central. A maior parte dos estados passou a ser governada por tenentes designados por Osvaldo Aranha e por Juarez Távora. Foi o caso de Santa Catarina, em que assumiu o general Ptolomeu de Assis Brasil.

Em agosto de 1931 o Governo Provisório publicou o Decreto 20.348, o qual ficou conhecido como "Código dos Interventores", pois visava justamente disciplinar a administração dos Estados, o que incluía a organização judiciária dos mesmos. Nesse sentido, apresentava uma série de normas relativas à magistratura, dispondo sobre a aposentadoria dos juízes e seus cargos, além de tratar da possibilidade de exame de autos judiciais e impossibilitar a apreciação dos atos dos interventores e dos prefeitos pelo Judiciário.

A partir da publicação do referido decreto, os Estados deveriam adaptar suas normas de organização judiciária às novas determinações do governo central. Em nove de setembro daquele ano, o então ministro da justiça Oswaldo Aranha enviou um telegrama a todos os interventores exigindo a aplicação do Código dos Interventores, o qual havia sido assinado apenas dez dias antes:

Não tendo ainda sido referendado o Codigo dos Interventores, que já foi, entretanto, divulgado pela imprensa, solicito-vos envieis, com urgencia, por telegramma quaesquer motivos que obstem a applicação do mesmo Codigo neste Estado (REPUBLICA, 1931).

71 Considerando que nesse período, as eleições para presidência de fato ocorreram, a vitória de Júlio Prestes gerou uma divisão política entre as principais lideranças, São Paulo e Minas Gerais. Contudo, o assassinato do vice de Getúlio, João Pessoa foi pretexto da Aliança Liberal contra Washington Luís. Com início de uma revolta, em 3 de novembro de 1930 Getúlio Vargas assumiu o poder. 
Dez dias depois, em 19 de setembro de 1931, o governo de Santa Catarina publicou o Decreto 157, o qual entraria em vigor em primeiro de outubro daquele ano através do Decreto 158, cuja finalidade era tão somente determinar a vigência da lei anterior. O Decreto 157 possuía quatrocentos e vinte e nove artigos, sendo que sua capa estampava o título "Codigo Judiciario do Estado de Santa Catharina" seguida pelo subtítulo "Livro I Organização Judiciaria"”2.

O livro II, entretanto, nunca foi publicado. Em uma busca pelo referido diploma legal nos acervos das bibliotecas da Universidade Federal de Santa Catarina, do Tribunal de Justiça e da Assembleia Legislativa do Estado, do Arquivo Público Catarinense, da Universidade de São Paulo, do Senado Federal, no Museu do Tribunal de Justiça de Santa Catarina e na Biblioteca Osni Régis, não foi encontrado nenhum registro. Somente o Arquivo Público e a biblioteca da Universidade Federal de Santa Catarina dispunham de uma cópia do livro I do "Código Judiciário de 1931". Por outro lado, em todas as demais bibliotecas e acervos foi encontrado o Código de 1928 e, em algumas, inclusive o de 1925. Isso pode ser explicado pelo fato do Decreto 157 de 1931 nunca ter sido considerado um código. Assim, o Código Judiciário de 1928 vigorou durante toda a década de 1930, apesar de ter sofrido algumas modificações, as quais foram mais significativas em relação às suas disposições acerca da organização judiciária.

Nesse sentido, o jornal "Republica" anunciou a publicação do Decreto 157 "como parte integrante do Codigo Judiciario"73. Um pouco mais de um mês depois, em 27 de outubro de 1931, a manchete "O primeiro ano do governo revolucionário em Santa Catarina” atribuía ao governo do general Ptolomeu de Assis Brasil a reforma do Código Judiciário de 1928. Ademais, não é difícil encontrar em jornais catarinenses comunicados oficiais, convocações para o júri e publicações de sentenças a partir de 1931 que fazem referência a artigos do Código Judiciário de 1928, inclusive em matérias que eram objeto do Decreto 157 de $1931^{74}$ -

72 SANTA CATARINA. Decreto 157, de 19 de setembro de 1931. Codigo Judiciario do Estado de Santa Catarina. Florianópolis, 1931.

73 Decreto n. 157. Republica. Florianópolis, p. 5-6. 20 set. 1931. p.5.

74 Alguns exemplos: no jornal "A Notícia”, publicado em Joinville em 11 de abril de 1932, na página 02, o edital para convocação do júri cita o artigo 76 do Código Judiciário de 1928 e não o artigo 71 do Decreto 157 de 1931, ainda que 
o que demonstra que o referido código de 1928 se manteve em vigor até a unificação nacional do direito processual.

Uma breve análise comparativa dos dois diplomas legais também não é capaz de revelar modificações profundas na organização judiciária prevista em cada um deles, de modo que não é possível afirmar que o Decreto 157 de 1931 tenha inaugurado uma nova forma de se organizar a justiça no Estado. Na verdade, o referido decreto parece ter mais reproduzido dispositivos já previstos anteriormente do que os alterado ${ }^{75}$.

O fato de as alterações terem sido pontuais, contudo, não significa que elas não tenham sido significativas. De modo geral, a leitura comparativa das legislações indica que o principal intuito do Decreto 157 de 1931 estava em atribuir maior controle do poder executivo sobre o judiciário, seguindo a orientação, assim, do "Código dos Interventores"76. Isso pode ser percebido, por exemplo, no fim da admissão de juízes de direito através de concurso e na extinção do Tribunal Correcional, a quem competia julgar crimes contra a saúde pública (art. 156, 157 e 158 com exceção de seus respectivos parágrafos, do Código Penal de 1890), a liberdade pessoal (art. 179, 180 e 184) e de trabalho (art. 204 a 206), o livre exercício de culto (art. 185 a 188), a inviolabilidade de segredo (art. 189 a 192) e a inviolabilidade do domicílio, desde que sem violência física (art. 196, caput, e 198), além dos delitos de lesão corporal (art. 303 e 306), duelo (art. 307 e 309), furto de menor valor (até $200 \$ 000$, art. 330, parágrafos 1, 2 e 3), loterias e rifas (art. 367 e

eles fossem praticamente idênticos; no jornal "A Gazeta”, publicado em 25 de outubro de 1939, a Secretaria do Interior e Justiça comentou o artigo 126 do Código de 1928, ainda que o artigo 107 do Decreto de 157 de 1931 dispusesse sobre a mesma matéria.

75 Nesse sentido, os dispositivos dos capítulos relativos ao Poder Judiciário, às autoridades auxiliares ao Poder Judiciário, à qualificação e revisão dos jurados, ao recurso de qualificação, serventuários e empregados da Justiça, entre outros, são cópias integrais de artigos do Código Judiciário de 1928.

76 O Decreto n. 20.348 de 1931 determinava que: "Art. 27. Logo que reorganizarem os seus tribunais judiciários, os Estados adotarão a regra de fazerem-se todas as nomeações ou promoções para cargos da magistratura mediante prévia e expressa aprovação do mais alto tribunal judiciário do Estado, em escrutínio secreto, salvo quando realizadas por indicação do mesmo tribunal, em lista de três nomes, no máximo" (BRASIL, 1930 [grifos nossos]). 
358), uso de armas (art. 377), contravenções de perigo comum (art. 379) e sociedade secreta (art. 382). Os juízes de direito assim como os distritais (que antes eram eleitos pelos cidadãos) passaram a ser nomeados livremente pelo interventor, desde que a indicação fosse aprovada pelo Superior Tribunal de Justiça ${ }^{77}$.

Já a competência do júri foi ampliada. Uma comparação desatenta entre Código de 1928 e o Decreto 157 pode levar a interpretação de que o rol de delitos a serem julgados pelo tribunal popular foi reduzido, uma vez que a legislação de 1928 colocava a competência do júri como regra geral $^{78}$, enquanto o Decreto 157 a descrevia em um rol específico de crimes. Na prática, no entanto, com a extinção do Tribunal Correcional a competência para julgar o delito de lesão corporal foi incorporada ao júri, para além dos delitos contra a vida que já lhe competiam anteriormente $^{79}$. Isso, não significa, em hipótese alguma, uma medida contrária ao movimento de centralização das infrações criminais nas mãos dos juízes de direito, uma vez que dos delitos que eram anteriormente julgados pelo Tribunal Correcional, apenas esse integrou o rol destinado ao júri. $\mathrm{Na}$ verdade, essa inclusão parece ter sido uma forma moderada de não retirar todos os crimes julgados pelos juízes distritais da competência popular, colocando a lesão corporal sob custódia do júri.

Pode-se afirmar, assim, que o Decreto 157 de 1931 foi publicado com o intuito de adaptar as normas do Código Judiciário de 1928 às demandas do novo regime, bem como é possível que o título "Código Judiciário” estampado na capa do Decreto 157 tenha sido utilizado como

77 Os cargos do Ministério Público já eram nomeados pelo Presidente do Estado durante a vigência do Código Judiciário de 1928, orientação que o Decreto 157 manteve.

78 Segundo o artigo 192, competia ao tribunal do júri "julgar os crimes communs não expressamente attribuidos a outra jurisdição" (SANTA CATARINA, op. cit., 1928).

79 Segundo o artigo 173 do Decreto 157, de 1931: “Art. 173. Ao tribunal do Jury compete: Julgar os crimes previstos nos seguintes artigos do Codigo Penal: I. Homicidio (arts. 294, parágrafos 1 e 2; 295, parágrafos 1 e 2, e 297). II. Infanticidio (art. 298). III Induzimento ou auxilio a suicidio (art. 299). IV Aborto (art. 300 a 302). V Lesões Corporaes (art. 304 e seu $\S$ unico)" (SANTA CATARINA, 1931). 
forma de enfatizar a reforma da organização judiciária e o acatamento das exigências do poder central.

Ademais, fica clara a intenção do "Código dos Interventores" de pressionar os Estados não só a submeterem o judiciário estadual ao Governo Federal através da expansão da interferência dos governadores (nesse caso indicados pelo Presidente da República), mas também pelo aniquilamento da justiça como lugar de exercício de cidadania, visto que com a outorga do Decreto 157 de 1931 extinguiu-se o Tribunal Correcional, o qual era composto por cidadãos eleitos por voto censitário, e que possuía uma competência relativamente ampla, conforme vimos. Ainda, tal tribunal pode ser considerado mais popular do que o próprio júri, uma vez que era presidido pelo juiz distrital, cargo que todos os cidadãos que soubessem ler e escrever poderiam se candida$\operatorname{tar}^{80}$, diferentemente da função de júri, destinada a um grupo seleto de pessoas, economicamente abastadas ${ }^{81}$. Ademais, com fim da eleição censitária do juiz distrital, funções importantes como a realização do flagrante e do corpo delito, a concessão de fiança e a execução da pena de prisão deixaram de ser competência de um representante do distrito, passando ao poder do indicado ao cargo pelo interventor federal, retirando, assim, a participação local no exercício da justiça criminal comum.

80 Conforme determinava o art. 44 do Código Judiciário de 1928: “Art. 44. - São condições essenciaes ao cargo de juiz districtal: I - Estar no goso dos direitos políticos, ou ter-lhes os requisitos. II - Ser domiciliado no districto, desde um anno antes, no mínimo, da data da eleição. III - Saber ler e escrever o português" (SANTA CATARINA, op. cit., 1928).

81 Em redação quase idêntica ao Código Judiciário de 1928, o Decreto 157 de 1931 previa que: “art. 46. Annualmente, no mez de outubro, os chefes de repartições fiscaes do Estado e do Municipio são obrigados a remetter ao Presidente do Tribunal do Jury uma relação dos funccionarios, com a especificação de seus vencimentos annuaes e outra dos contribuintes dos impostos territorial, predial e de indústria e profissão, com a indicação da contribuição a que estão sujeitos e suas residencias. Esta ultima relação conterá cincoenta a sessenta nomes dos maiores contribuintes de cada um daquelles impostos, que sejam eleitores. [...] Art. 48. Recebidas as listas, o presidente do Jury mandara transcreve-las em edital, para o que nellas for incluido, ou não, poder reclamar contra a indevida inclusão, ou omissão, dentro do prazo de dez dias" (SANTA CATARINA, 1937). 


\section{A UNIFICAÇÃo NACIONAL do PROCESSO PENAL}

Conforme já demonstrado, em 1930 Getúlio Vargas, tensionado pela instabilidade política da Primeira República, assumiu ao poder, realizando diversas transformações para romper com os poderes político e jurídico da velha política. Já em 1937, o então presidente cancelou a eleição de 1938 para submeter o Brasil a um regime ditatorial outorgando uma nova Constituição. O golpe de Estado foi justificado pelo Plano Cohen, um documento falso, o qual alertava sobre uma conspiração comunista em curso no país.

No Estado Novo, Getúlio Vargas concentrou ainda mais o poder no Executivo, implementou a censura e ainda reduziu liberdades, além de produzir grandes transformações no direito, inclusive em matéria processual. Tanto o direito processual penal como o direito processual civil ganharam um código colocando fim aos códigos estaduais e unificando o processo em todo país ${ }^{82}$.

Convém salientar, entretanto, que a Constituição de 1937, com redação bastante similar no tema à de 1934, também autorizava a competência suplementar dos Estados nos casos previstos no artigo $18^{83}$, inclusive sobre matéria processual judicial e extrajudicial desde que observadas as exigências de lei federal. Sabadell ${ }^{84}$ explica que essa competência só era autorizada em casos de extrema necessidade regional, além de depender de aprovação do governo federal.

82 NUNES, Diego. O Percurso dos crimes políticos durante a Era Vargas (19351945): do direito penal político italiano ao direito da segurança nacional brasileiro. Dissertação (Mestrado em Direito) - Curso de Pós-Graduação em Direito, Universidade Federal de Santa Catarina, Florianópolis, 2010.

“Art 18 - Independentemente de autorização, os Estados podem legislar, no caso de haver lei federal sobre a matéria, para suprir-lhes as deficiências ou atender às peculiaridades locais, desde que não dispensem ou diminuam es exigências da lei federal, ou, em não havendo lei federal e até que esta regule, sobre os seguintes assuntos: [...], g) processo judicial ou extrajudicial; Parágrafo único - Tanto nos casos deste artigo, como no do artigo anterior, desde que o Poder Legislativo federal ou o Presidente da República haja expedido lei ou regulamento sobre a matéria, a lei estadual ter-se-á por derrogada nas partes em que for incompatível com a lei ou regulamento federal". 
Por sua vez, o Código de Processo Penal foi editado em 1941 sob o cenário ditatorial do Estado Novo. Desde a Revolução de 1930 o governo estava empenhado na unificação da legislação processual, com a instalação da subcomissão do código do processo penal pela comissão legislativa ${ }^{85}$. Com a afirmação da unidade legislativa pela constituição federal de $1934^{86}$, o então ministro da Justiça Vicente Ráo capitaneou uma comissão que em poucos meses fez um projeto inovador, com novidades como o juízo de instrução criminal ${ }^{87}$. O projeto foi abandonado com a mudança de regime, quando o ministro da Justiça Francisco Campos, o jurista brasileiro responsável pela edição da Constituição de 1937 e do Código de Penal de 1940, assume os trabalhos ${ }^{88}$.

85 SILVEIRA, Mariana de Moraes. Revistas em tempos de reformas: Pensamento Jurídico, Legislação e Política nas Páginas dos Periódicos de Direito (19361943). Dissertação (Mestrado em História), Universidade Federal de Minas Gerais, Belo Horizonte, 2013; SILVEIRA, Mariana de Moraes. Direito, ciência do social: o lugar dos juristas nos debates do Brasil dos anos 1930 e 1940. Estudos Históricos, Rio de Janeiro, vol. 29, no 58, p. 441-460, maio-agosto 2016; SILVEIRA, Mariana de Moraes. Técnicos da legalidade: juristas e escrita das leis (Argentina e Brasil, primeira metade do século XX). Estudios Sociales Contemporáneos, v. 17, p. 86-102, 2017. COSTA MANSO, O. O tribunal popular. Archivo Judiciario, Rio de Janeiro, 5 mai. 1935, p. 65.

87 "O Projeto de Código do Processo Penal, que a seguir publicamos, foi organizado por uma comissão na qual figuravam, como presidente, o Dr. Vicente Ráo, então Ministro de Estado da Justiça e Negócios Interiores, e os Drs. Gama Cerqueira, Bento de Faria e Plínio Casado, os dois primeiros professores desta Faculdade e os últimos Ministros da Côrte Suprema. Na Camara dos Deputados, o Projeto provocou, no seio das comissões, brilhantes pareceres dos notáveis juristas que as compunham, e o Primeiro Congresso Nacional de Direito Judiciário, com o concurso de magistrados vindos de todos os Estados, chegou a aprovar as diretrizes fundamentais disse Projeto. Quer haja servido, quer não, para os trabalhos recentemente realizados, de organização de novo Projeto - o que adiante se segue merece figurar nas páginas desta Revista, por seu valor próprio e pela colaboração, que lhe deram, dois professores desta casa". NOTA EDITORIAL. Projeto do Código do Processo Penal da República dos Estados Unidos do Brasil. Revista da Faculdade de Direito - Universidade de São Paulo, v. XXXIV, fasc. III, set.-dez./1938. 
Segundo o relato de Narcélio de Queiroz ${ }^{89}$, Campos monta a comissão quando vira ministro do novo regime para a confecção da lei do júri, dada a urgência pelo silêncio da constituição de 1937 sobre o tema. Além de Queiroz, são convocados Nélson Hungria, Vieira Braga e Magarinos Torres. Este último, dadas várias divergências, deixa de fazer parte ${ }^{90}$ após a emanação do Decreto-Lei $\mathrm{n}^{0} 167$, de 5 de janeiro de 1938, que "Regula a instituição do Juri”, assumindo Candido Mendes para a continuação dos trabalhos de preparação do código. A primeira versão fora entregue em abril de 1938, ao mesmo tempo em que Alcântara Machado entrega o projeto de Código Criminal. Isso teria feito Vargas mandar Campos segurar o CPP para adaptá-lo. Para esta nova empreitada, juntam-se Roberto Lyra e Florêncio de Abreu, dado o falecimento de Mendes em 1939. Queiroz faz elogios a Campos por sua participação direta ${ }^{91}$.

Em síntese, para Nunes,

o código de processo penal era uma necessidade, haja vista que a constituição de 1891 deixara a lei processual a encargo de cada unidade da federação. Com a mudança de regime, uma nova codificação que desse um sentido único - a "defesa social” - era objetivo do governo ${ }^{92}$.

89 QUEIROZ, Narcélio de. O novo código de processo penal. Archivo Judiciário, Rio de Janeiro, 5 jan. 1943, p. 9.

90 MAGARINOS TORRES, Antonio Eugenio. O jury na commissão de Código de Processo Penal para o Brasil. Revista de Direito Penal, Rio de Janeiro, v. VIII, a. III, jan., 1935.

91 QUEIROZ, op. cit., p. 9.

${ }_{92}$ NUNES, Diego. Processo Legislativo para além do Parlamento em Estados Autoritários: uma análise comparada entre os Códigos Penais Italiano de 1930 e Brasileiro de 1940. Seqüência: Florianópolis, v. 37, n. 74, 2016, p. 168. Veja-se o seguinte exemplo: "Caso típico e gritante é o do direito processual, principalmente do processual penal, que deveria estar sujeito a um regime unitário, pela projeção direta que desempenha social e politicamente [...] O Direito é, neste período histórico, essencialmente nacional. Não se poderiam admitir leis regionalistas, que são, sem duvida, as causas remotas dos movimentos separatistas". ASSIS RIBEIRO, C. J. Tendencias do novo direito brasileiro. Revista Forense, Rio de Janeiro, nov., 1941, p. 243. 
O Decreto-Lei n ${ }^{\circ} 3.689$ de 3 de outubro de 1941 trouxe a lume a codificação processual penal unificada ${ }^{93}$. Francisco Campos $^{94}$ na exposição de motivos do Código de Processo Penal enfatizou o caráter único dessa legislação: "havia um dispositivo constitucional a atender, e sua execução não devia ser indefinitivamente retardada". Assim, quanto ao trabalho realizado da comissão anterior, Campos ${ }^{95}$ ressaltou:

Desde já se podia prever para breve tempo a efetiva remodelação da nossa antiquada lei penal material, deixava de ser aconselhado que se convertesse em lei o projeto acima aludido, pois estaria condenado a uma existência efêmera.

Importante destacar aqui que "a preocupação com a modernização do Estado, partindo das instituições e chegando à legislação, é uma marca notória do regime Vargas. Inúmeros são os legados nesse sentido"96. Campos ${ }^{97}$ sintetizou a importância de um Código de Processo Penal único para afirmar a homogeneidade do direito brasileiro quando disse: "se não for convertido em lei, não estará apenas regulada a atuação da justiça penal em correspondência com o referido novo Código Penal e com a Lei de Contravenções Penais [...].” Afinal,

O projeto do Código de Processo Penal, resultando de um imperativo da Constituição de 1937 - como o era da de 1934, mas quedos tumultuosos legisladores da Segunda República não souberam realizar - já está concluído. De par com a necessidade de coordenação das regras do processo penal num código único partia todo

${ }^{93}$ É interessante observar que, durante o regime do Estado Novo, houve uma centralização do poder com a concentração da competência legislativa ao Presidente da República. Por isso, as reformas às leis anteriores se deram por meio de decreto, com a colaboração de comissões técnicas.

94 CAMPOS, Francisco. Exposição de motivos do Código de Processo Penal. In: MIRABETE, Júlio Fabbrini. Processo penal. 11. ed., rev. e atual. até dezembro de 2000. São Paulo: Atlas, 2001, p. 916.

95 Ibidem, p. 915.

96 NUNES, op. cit., 2016, p. 170.

97 CAMPOS, op. cit., p. 915. 
o Brasil, impunha-se o seu aperfeiçoamento ao objetivo de maior facilidade e energia da ação repressiva do Estado ${ }^{98}$.

Podemos dizer, portanto, que as reformas no direito penal e processual penal marcaram o legado legislativo desejado pela Era Vargas, ou seja, a homogeneidade do direito nacional. Nesse sentido, Nélson Hungria, Florêncio de Abreu e Narcélio de Queiroz, magistrados e membros da comissão de elaboração do código, entendiam que ele era capaz de atender as diferenças regionais "do Brasil litorâneo e do Brasil central"99.

Neste sentido, o próprio ministro Campos ${ }^{100}$, ao longo da exposição de motivos destacou esse caráter do código de processo penal, ao dizer que: "Estará ao mesmo passo, finalmente realizada a homogeneidade do direito judiciário penal no Brasil, segundo reclamava, de há muito, o interesse da boa administração da justiça, aliado ao próprio interesse da unidade nacional".

Tal como exposto, Campos ${ }^{101}$ sustentou que "[...] o projeto não altera o direito atual, senão para corrigir imperfeições apontadas pela experiência, dirimir incertezas da jurisprudência ou evitar ensejo à versatilidade dos exegetas". Para o jurista, "tanto quanto o permitiu a orientação do projeto, foi aproveitado o material da legislação atual. Muito se respingou em vários dos códigos de processo penal estaduais [...]”102.

Tudo isso determinava o vigor das normas processuais penais. Para Campos a reforma penal exercia um papel modernizador:

De par com a necessidade de coordenação sistemática das regras do processo penal num Código único para todo o Brasil, impunha-se o seu ajustamento aos objetivos de maior eficiência e energia da ação repressiva do Estado contra os que delinquem ${ }^{103}$.

98 CAMPOS, Francisco. Notas e informações. Revista Forense, Rio de Janeiro, Mai., 1939. p. 369.

99 NOTAS E COMENTÁRIOS. O novo código de processo penal. Revista Forense: Rio de Janeiro, Jan., 1942. p. 295.

${ }^{100}$ Ibidem, p. 915.

${ }^{101}$ Ibidem, p. 923.

${ }^{102}$ Ibidem, p. 923.

${ }^{103}$ Ibidem, p. 915. 
Para a construção desse novo arranjo processual, as formas de ações penais inseridas no código eram ordinárias e sumárias. Sabadell ${ }^{104}$ explica que quanto às sumárias, essas ficavam limitadas a casos de ofensas - contravenções penais conforme Decreto-Lei no 3.688/1941 - ou a crimes considerados menos graves. Vale acrescentar que também havia um procedimento especial para aplicação de medidas de segurança.

A partir dessa divisão, as ações penais obedeceram ao princípio “[...] ne procedat judex ex officio, que ditado pela evolução do direito judiciário penal e já consagrado pelo novo Código Penal, reclama a completa separação entre juiz e o órgão da acusação [...]"105. O Ministério Público tinha exclusividade para a iniciativa das ações penais, ressalvadas as hipóteses de contravenção penal, nas quais o procedimento ex officio ficou mantido “[...] dado o caráter essencialmente preventivo, assume, na espécie, a sanção penal, devem ser sujeitadas a um processo particularmente célere, sob pena de frustrar-se a finalidade legal”" ${ }^{106}$.

A ação penal tinha como objetivo qualificar os fatos como infração penal, portanto, a legislação penal brasileira estabeleceu como regra básica a ação penal pública, por denúncia do Ministério Público, ou privada, mediante queixa do ofendido. O Código Penal de 1940 previa expressamente que a apuração de determinados delitos somente se procederia com queixa. Nesse sentido, podemos citar como exemplos os crimes de dano em domínio particular, corrupção de menores, violência carnal sem resultado morte ou dano grave à saúde, rapto, adultério, parto suposto, calúnia, injúria, lenocínio praticado pelo marido contra a esposa e crimes contra a propriedade intelectual. Não por acaso, matérias que já no Código Judiciário catarinense de 1928 foram legadas ao juiz togado.

Cabe resumidamente abordar que o processo criminal, no rito comum, começava com a abertura do inquérito policial. Nos termos da nova lei, recebida a notícia crime ou em caso de flagrante delito, a autoridade policial deveria tomar todas as medidas necessárias para a coleta de provas, a fim de garantir o estado de conservação das coisas, assim como promover o interrogatório de testemunhas e do acusado, ou ainda

\footnotetext{
${ }^{104}$ SABADELL, op. cit.

105 CAMPOS, op. cit., p. 917.

106 Ibidem.
} 
solicitar a prisão preventiva, fundamentando as razões e provas para tanto - procedimento similar ao previsto no CJSC/1928 que o dispunha como regra básica do crime de homicídio.

Importante sublinhar, que o inquérito policial foi mantido tendo em vista sua função como:

[...] instrução provisória antecedendo à propositura da ação penal, um argumento dificilmente contestável: é ele uma garantia contra apressados e errôneos juízos, formados quando ainda persiste a trepidação moral causada pelo crime ou antes que seja possível uma exata visão de conjunto dos fatos, nas suas circunstâncias objetivas e subjetivas ${ }^{107}$.

Nesse novo contexto, o novo Código de Processo Penal de 1941 consolidou a fase de investigação e a fase de produção de prova, a defesa do acusado e o julgamento, criando a jurisprudência em "nível nacional" - uma vez que colocava fim às divergências regionais da jurisprudência devido aos costumes locais desses tribunais, pelos quais não era possível igualar ${ }^{108}$. Pode-se já vislumbrar que a legislação processual penal validou um sistema processual misto, visto que previa uma fase de investigação (inquisitorial) e outra de produção de prova, defesa e julgamento (acusatória).

De tal maneira, analisando o texto do código, podemos constatar, por exemplo, que as provas tinham sentido inquisitório ao atribuírem ao juiz uma pro-atividade em relação a provas complementares e supletivas. Outra inovação foi a ampliação da definição e dos casos de flagrante delito (próprio, impróprio e presumido) e a descrição das hipóteses obrigatórias de prisão preventiva como instrumento da efetivação do direito penal. Outro aspecto do código que vale a pena a ser ressaltado era a reparação do dano "ex delicto" que "[...] ajustando-se ao Código Civil e ao novo Código Penal, mantém a separação entre ação penal e ação civil ex delicto, rejeitando o instituto ambíguo da constituição da parte civil no processo penal” ${ }^{109}$.

\footnotetext{
107 Ibidem.

108 SABADELL, op. cit.

109 CAMPOS, op. cit., p. 917
} 
Enfim, o tribunal do júri, protagonista na discussão feita até aqui, restou competente para julgar apenas os crimes de homicídio, induzimento, instigação ou auxílio ao suicídio, aborto e infanticídio. Nas palavras de Campos "[...] deixou de ser uma abdicação, para ser uma delegação do Estado, controlada e orientada no sentido superior interesse da sociedade" ${ }^{110}$. Isso porque:

Privado na sua antiga soberania, que redundava, na prática, numa sistemática indulgência para com os criminosos, o júri está, agora, integrado na consciência de suas graves responsabilidades e reabilitado na confiança geral ${ }^{111}$.

Perceba-se que a crítica do ministro Campos era muito semelhante ao que já fora afirmado pela imprensa catarinense quando da redução de competência do júri local. Na trincheira oposta, encontrava-se Magarinos Torres. Ele usou a Revista de Direito Penal, promovida pela Sociedade Brasileira de Criminologia, que presidiu, como uma tribuna em favor da manutenção do júri e contra os reformismos, que depois se concretizaram na reforma de 1938 e, por consequência, no código de processo em 1941: escrevia artigos, publicava notas e conferências de outros juristas ${ }^{112}$.

Na perspectiva do tecnicismo jurídico-penal foi a crítica de Nelson Hungria em relação do Tribunal do Júri, no que se refere ao paradigma de juízes leigos ${ }^{113}$. Ainda que tenha entendido ser uma reforma que "não rompe sistematicamente com a nossa tradição jurídica” nem adotou

${ }^{110}$ Ibidem, p. 922.

111 Ibidem.

${ }^{112}$ Ver, p. ex., MAGARINOS TORRES, Antonio Eugenio. Processo penal do juri no Brasil. Revista de Direito Penal, Rio de Janeiro, v. XX, fasc. II, a. V, jan./1938. p. 239-241, e MAGARINOS TORRES, Antonio Eugenio. Processo penal do juri no Brasil. Revista de Direito Penal, Rio de Janeiro, v. XXIV, fasc. II, a. VII, fev./1939. p. 106, quando se isenta da autoria da lei do júri, por discordar de várias posições da comissão, especialmente sobre a soberania do veredicto.

113 SONTAG, Ricardo. "A eloqüência farfalhante da tribuna do júri": o tribunal popular e a lei em Nelson Hungria. História, São Paulo, v. 28, n. 2, p. 267-302, 2009. 
"critérios da legislação do novo mundo"114, segundo o autor, o júri se tornava o culto à incompetência no Direito e a soberania do Tribunal do Júri gerava sentenças controversas e muitas impunidades. Sontag ${ }^{115}$ destaca que, segundo Hungria, "[...] o júri teria produzido um direito penal 'romântico e emocional'". Portanto, pode-se afirmar que caberia a um colegiado de pessoas do povo "julgar" se réu era culpado ou não. A seleção desses jurados era criteriosa e rigorosa ${ }^{116}$.

É possível perceber, de modo geral, que o Código Processo Penal passou a prever a responsabilidade dos jurados, que em síntese, era multa para o jurado que não comparecesse e à recusa sem justificativa, salvo nos casos de impedimento. O discurso sobre o júri de Hungria expressava apoio ao tecnicismo:

O objetivo fundamental do tecnicismo, não só na versão de Nelson Hungria, era colaborar com os juízes para uma adequada aplicação da norma positivada, conseqüentemente, um jurado, que não tem o conhecimento da ciência jurídica, correria sempre o risco de não aplicá-la corretamente, elidindo a sua efetividade judicial, bem como a defesa social colocada como objetivo político final de todo o sistema penal ${ }^{117}$.

Nessa ótica, pode-se verificar ainda que Hungria criticava o júri com relação à atuação dos advogados criminais. Na prática, o Código de Processo Penal passou a restringir essa dialética tida como exagerada em relação ao advogado e, assim, o júri adquiria característica de um eficaz instrumento punitivo estatal para a defesa do interesse social ${ }^{118}$.

Como visto anteriormente, o novo Código diminuiu a soberania do júri. A partir de então, cabia Recurso de Apelação das decisões do júri, a seleção dos jurados obedecia a critérios da lei, redução dos debates em

\footnotetext{
${ }^{114}$ HUNGRIA, Nélson. As inovações do projeto de Código do Processo Penal brasileiro. Revista Forense, Rio de Janeiro, out./1938, p. 170.

115 Ibidem, p. 273.

${ }^{116}$ Ibidem. Veja-se, a propósito, a elogiosa crônica de BARBOSA LIMA SOBRINHO, Antônio José. A propósito do júri. Revista Forense, Rio de Janeiro, jul., 1939. p. 185.

117 Ibidem, p. 289.

118 Ibidem.
} 
plenário e maior atuação do juiz togado ${ }^{119}$. Com o fortalecimento da ação dos juízes togados "[...] daí a importância dessas mudanças -, seriam, para ele, tendencialmente mais aptos a resistirem à retórica enganadora dos advogados" 120 .

Uma das principais modificações foi em relação aos atores processuais, dada a diversidade dos arranjos locais. Como consequência, a magistratura, a polícia e o Ministério Público não eram estabelecidos com critérios iguais e segundo estatutos padronizados. O novo Código de Processo Penal passou a estabelecer uma nova administração da justiça. Campos referiu que o espírito do código era no "[...] sentido de obter equilíbrio entre o interesse social e o da defesa individual, entre o direito do Estado à punição dos criminosos e o direito do indivíduo às garantias e seguranças de sua liberdade" ${ }^{121}$. O ministro da Justiça ainda reforçou que o fundamento da lei processual penal “[...] não transige com as sistemáticas restrições ao poder público, não o inspira, entretanto, o espírito de um incondicional autoritarismo do Estado ou de uma sistemática prevenção contra os direitos e garantias individuais" ${ }^{22}$.

Não obstante tais considerações sobre o Código de Processo Penal ser fruto de um regime autoritário, na exposição de motivos Campos neutraliza a violenta centralização de Vargas, aludindo que

[...] se, por um lado, os dispositivos do projeto tendem a fortalecer e prestigiar a atividade Estatal na sua função repressiva, é certo, por outro lado, que se asseguram, com muito, mais eficiência que a legislação atual, a defesa dos acusados ${ }^{123}$.

Dentre outras modificações não mencionadas nesse trabalho, podemos concluir que o Código de Processo Penal surgiu em um período de forte centralização política que, no âmbito do direito penal e processual penal era também uma forma de reafirmar o poder central pelo respeito à

119 SONTAG, op. cit., p. 279.

${ }^{120}$ Ibidem, p. 275.

${ }^{121}$ Campos, op. cit., 1941, p. 923.

${ }^{122}$ Ibidem, p. 923.

123 Ibidem. 
norma ${ }^{124}$. Colocava-se fim aos códigos estaduais e afirmava-se um direito penal e processual penal próprio do Estado Novo, que se pautava pela técnica ${ }^{125}$. Por outro lado, manter o júri, ainda que desidratado, era uma forma de assegurar o pedigree democrático do regime ${ }^{126}$.

Tal código foi ação de um governo autoritário, pautado por um ideal tecnicista. Vigente até hoje, com modificações realizadas por regimes democráticos posteriores, é um mosaico em que se encontram muitas disposições fundamentadas em um ideal de defesa social típico do Estado Novo, que colocava os direitos individuais em segundo plano em relação aos "interesses da sociedade", tutelada pelo regime. Mas, também, com inovações desejadas pela doutrina e elites sociais. Dentre elas, ressalta-se a diminuição do papel do tribunal do júri, que se apresentava desconectado com um projeto de modernização que levasse em conta a participação popular na administração da justiça.

\section{CONCLUSÕES}

O presente trabalho buscou discutir as leis processuais que caracterizavam a administração da justiça no Brasil entre a Primeira República, quando se consolidou o sistema federativo, e a Era Vargas, a qual rompeu politicamente com a manutenção do poder pelas oligarquias. Para analisá-las, buscamos sempre questionar o conteúdo das fontes, com o objetivo de verificar o sentido empregado aos discursos, de modo a não os acatar como "verdades", mas sim enquanto narrativas interessadas.

Desse modo, pudemos observar a partir da análise do caso catarinense, a importância do Judiciário para a conservação do poder político. A começar, vimos que a competência para legislar em matéria processual

\footnotetext{
${ }^{124}$ Para além das falas de Francisco Campos já transcritas, veja-se a ambiguidade de Roberto Lyra: "No decênio que se completa êste ano, impôs-se, desde logo, a ordem, com a consolidação de tôdas as leis vigentes, antes dispersas. Não só o ensino, o estudo, a consulta, a aplicação lucraram, pois a concentração das normas, facilitando a difusão, serve à eficácia de sua ação intimidante e educativa”. LYRA, Roberto. Um decênio de reformas penais. Revista Forense, Rio de Janeiro, dez., 1940, p. 201.

125 SONTAG, op. cit.

${ }^{126}$ FRANCO, Ary Azevedo. O jury no Estado Novo. São Paulo: Saraiva, 1939.
} 
foi prevista de forma residual aos entes federativos na Constituição Federal de 1891. Assim, ainda que os Estados tivessem o poder de publicar suas próprias leis e códigos de direito processual, a Federação Nacional também poderia fazê-lo. Tratava-se de uma competência compartilhada, da qual o Estado Federal não abriu mão. Isso levou a discussões quanto aos limites do alcance das normas federais em matéria processual, gerando hesitação por parte do poder local em contrariá-las, conforme vimos no relato de D’Aquino. Ao considerarmos a forte repressão que os movimentos de oposição ao governo federal sofreram em Santa Catarina durante a década de 1890, o argumento do jurista catarinense parece fazer sentido.

Por outro lado, dentro da própria organização política local, o Judiciário se mostrou enquanto peça importante para o poder político do Executivo. Em um primeiro momento, logo após a proclamação da República, os órgãos superiores do Judiciário Catarinense foram alvo de disputa política, sendo extintos, desmembrados ou renovados em seus quadros profissionais. Com a progressiva estabilização do poder político, a primeira lei de organização judiciária do estado foi publicada em 1911. O processo penal, entretanto, não sofreu modificações em relação ao Império, de modo que até 1925 aplicava-se o Código de Processo Criminal de 1832 em todo o território catarinense.

De fato, parecia haver um desinteresse por parte do estado catarinense em legislar sobre o processo penal. Ainda que a constante ameaça de reforma do Código Penal de 1890 pudesse se constituir enquanto um argumento válido para o adiamento da organização de um código próprio, ela não explica por que, mesmo sem uma reforma do direito material, as normas processuais catarinenses foram publicadas. As fontes documentais encontradas apontaram argumentos que justificavam a demora do advento de um código; contudo, elas não foram capazes de nos revelar os motivos para que, depois de quase trinta e cinco anos, optou-se por se organizar o primeiro Código Judiciário Catarinense, ainda sob a vigência do Código Penal de 1890.

Tal código, entretanto, foi substituído por outro em pouco menos de três anos. Em relação ao processo penal, a principal alteração foi a redução do rol de competências do Tribunal do Júri. No mais, a íntima relação com o poder político manteve-se presente, de forma que a palavra final para a nomeação dos principais cargos da magistratura e 
do Ministério Público era do Governador do Estado. Por outro lado, é interessante notar que, apesar de existir uma relação de submissão do Judiciário ao Executivo, a justiça também era um espaço de realização democrática, visto que o julgamento da maior parte dos crimes durante o período era de competência do júri e dos juízes distritais, eleitos pela população. Assim, ainda que a alteração de normas processuais penais pelo Código Judiciário de 1928 tenha sido resultado da discussão acerca da capacidade técnica e intelectual do tribunal popular em julgar determinados delitos, a realização da justiça manteve seu caráter comunitário.

Com o advento da Era Vargas e a outorga do Código dos Interventores, o Estado de Santa Catarina se viu na necessidade de realizar uma reforma judiciária, a qual se deu através da publicação do Decreto 157 de 1931. Apesar das alterações na organização judiciária e nas normas processuais penais terem sido pontuais, elas foram determinantes para o estabelecimento de um novo modo de se fazer justiça. Extinguiu-se o Tribunal Correcional, administrado por magistrados eleitos, pôs-se fim à eleição popular dos juízes distritais, alocando praticamente todo o rol de crimes que estes eram competentes para julgar ao juiz de direito. Se antes parte da população participava da realização da justiça, a partir desse momento sua atuação foi restringida ao julgamento de poucos casos, visto que até a execução das penas de prisão, a concessão de fiança e a realização de exames de corpo delito e do auto de flagrante, entre outros procedimentos, deixaram de ser praticadas por um representante da comunidade local.

Enquanto o poder executivo estatal passava a ter ainda mais ingerência sobre o judiciário, a União Federal centralizava o poder, controlando os entes federativos através da nomeação de seus chefes de estado. O Código de Processo Penal de 1941 parece ter sido, assim, consequência desse movimento de centralização política. Apesar das mudanças significativas impostas pelo Código dos Interventores no processo penal, o fato de a organização judiciária ser determinada pelos poderes locais ainda poderia permitir a existência de algum vínculo comunitário com a atividade jurisdicional. A partir do Estado Novo, os entes federativos deixaram de ter competência para organizarem o poder judiciário estadual. Ademais, conforme vimos, ainda que as cartas constitucionais de $1934 \mathrm{e}$ de 1937 não excluíssem a possibilidade de os entes federativos legislarem em matéria processual, a condicionavam à aprovação do governo federal. 
Nesse sentido, o Código de Processo Penal consolidou a unificação federal das normas processuais penais. Com a nova legislação, as atribuições do júri passaram a ser ainda mais restritas em Santa Catarina, se comparadas ao que previa o Decreto 157, de 1931. Campos, ao comentar o código, justificou a restrição da competência do tribunal popular pela necessidade de maior repressão criminal e de maior controle estatal do júri, de modo a orientá-lo ao "interesse superior" da sociedade. Resta claro, portanto, que a concepção de justiça aqui não está relacionada ao sentimento ou às percepções populares do que era "justo" para determinado caso, mas sim à ideia de repressão criminal. Foi nesse sentido que Campos afirmou que o Código de Processo Penal tornaria a justiça mais eficiente.

De modo geral, portanto, é possível observar que a Era Vargas rompeu com o modo e a concepção anterior de se fazer justiça criminal. Gradativamente, ao longo dos anos 1930, a justiça criminal deixou de dialogar em última instância com os anseios da comunidade local, a qual até então detinha a palavra final acerca da condenação ou da absolvição do acusado, e passou a ser uma justiça asséptica, na qual a norma deveria ser aplicada por um profissional de forma igual para todos, de modo que qualquer infração à lei deveria ser reprimida independentemente dos ímpetos sociais, correspondendo, assim, aos ideais de defesa social do Estado.

\section{REFERÊNCIAS \\ FONTES}

A CONSTITUIÇÃO Federal e as constituições dos estados da república do Brazil. V. I-II. Pelotas: Livraria Universal, 1895-1896.

ASSIS RIBEIRO, C. J. Tendencias do novo direito brasileiro. Revista Forense, Rio de Janeiro, nov., 1941.

BARBOSA LIMA SOBRINHO, Antônio José. A propósito do júri. Revista Forense, Rio de Janeiro, jul., 1939.

BRASIL. Constituição da República dos Estados Unidos do Brasil. Prudente José de Mores Barros, Presidente do Congresso. Rio de Janeiro, fev. 1891.

BRASIL. Constituição da República dos Estados Unidos Do Brasil (de 16 de julho de 1934). Rio de Janeiro, RJ: Presidente da República dos Estados Unidos do Brasil, 
1934. Disponível em: <http://www.planalto.gov.br/ccivil_03/constituicao/ constituicao34.htm>. Acesso em: 18 dez. 2019.

BRASIL. Constituição dos Estados Unidos do Brasil (de 10 de novembro de 1937). Rio de Janeiro, RJ: Presidente da República dos Estados Unidos do Brasil, 1937. Disponível em: <http://www.planalto.gov.br/ccivil_03/Constituicao/Constituicao37.htm>. Acesso em: 18 dez. 2019.

BRASIL. Decreto-Lei $n^{o} 3.689$, de 3 de outubro de 1941. Promulga o Código de Processo Penal, 1941. Disponível em: <https://www2.camara.leg.br/legin/fed/ declei/1940-1949/decreto-lei-3689-3-outubro-1941-322206-publicacaooriginal-1-pe.html>. Acesso em: 03 ago. 2020.

BRASIL. Decreto-Lei $n^{\circ} 2.848$, de 7 de dezembro de 1940. Promulga o Código Penal, 1940. Disponível em: <https://www2.camara.leg.br/legin/fed/declei/1940-1949/ decreto-lei-2848-7-dezembro-1940-412868-publicacaooriginal-1-pe.html>. Acesso em: 27 ago. 2020.

BRASIL. Decreto $n^{\circ}$ 847, de 11 de outubro de 1890: Promulga o Codigo penal. Rio de Janeiro, 1890b. Disponível em: <http://www.planalto.gov.br/ccivil_03/ decreto/1851-1899/d847.htm>. Acesso em: 10/08/2020.

BRASIL. Decreto $n^{\circ} 848$, de 11 de outubro de 1890: Organiza a Justiça Federal. Rio de Janeiro, 1890b. Disponível em:< http://www.planalto.gov.br/ccivil_03/ decreto/1851-1899/D848.htm>. Acesso em: 10/08/2020.

BRASIL. Decreto $n^{o}$ 3.084, de 5 de Novembro de 1898: Approva a Consolidação das Leis referentes á Justiça Federal. Rio de Janeiro, 1898a. Disponível em: <http:// www.planalto.gov.br/ccivil_03/decreto/1851-1899/D848.htm>. Acesso em: 10/08/2020.

BRASIL. Decreto n. 20.348 de 29 de Agosto de 1931. Rio de Janeiro, 1931. Disponível em: <https://www2.camara.leg.br/legin/fed/decret/1930-1939/decreto-20348-29-agosto-1931-517916-publicacaooriginal-1-pe.html>. Acesso em: $10 / 08 / 2020$.

BRASIL. Lei $n^{\circ} 515$, de 3 de novembro de 1898: Providencia sobre o julgamento dos crimes de moeda falsa, contrabando, peculato, falsificação de estampilhas, sellos adhesivos, vales postaes e outros, qualificados nos arts. 221 a 223, 239 a 244, 246, 247, 250 e 265 do Codigo Penal. Rio de Janeiro, 1898b. Disponível em: <https://www2.camara.leg.br/legin/fed/lei/1824-1899/lei-515-3-novembro-1898-540059-publicacaooriginal-39841-pl.html>. Acesso em: 10/08/2020.

BRASIL. Emenda Constitucional de 3 de setembro de 1926. Rio de Janeiro, 1926. Disponível em: <http://www.planalto.gov.br/ccivil_03/constituicao/Emendas/ Emc_anterior1988/emc\%20de\%203.9.26.htm>. Acesso: 16/08/2020. 
CAMPOS, Francisco. Exposição de motivos do Código de Processo Penal. In: MIRABETE, Júlio Fabbrini. Processo penal. 11. ed., rev. e atual. até dezembro de 2000. São Paulo: Atlas, 2001.

CAMPOS, Francisco. Notas e informações. Revista Forense, Rio de Janeiro, mai., 1939.

COSTA MANSO, O. O tribunal popular. Archivo Judiciario, Rio de Janeiro, 5 mai. 1935.

D’AQUINO, Ivo. Parecer da Comissão Especial. In.: SANTA CATARINA. Lei n ${ }^{0} \mathrm{n}$. 1526, de 14 de novembro de 1925. Codigo Judiciario do Estado de Santa Catarina. Florianópolis, SC: Officinas A Elect. da Imprensa Official, 1926.

Decreto n. 157. Republica. Florianópolis, p. 5-6. 20 set. 1931.

Decreto n. 171. República. Florianópolis, p. 5.07 nov. 1931.

FRANCO, Ary Azevedo. O jury no Estado Novo. São Paulo: Saraiva, 1939.

HUNGRIA, Nélson. As inovações do projeto de Código do Processo Penal brasileiro. Revista Forense, Rio de Janeiro, out./1938.

KONDER, Adolpho. Mensagem apresentada á Assembléa Legislativa, a 29 de julho de 1929, pelo doutor Adolpho Konder, Presidente do Estado de Santa Catharina. Disponível em: <http://memoria.bn.br/docreader/DocReader.aspx?bi$b=873438 \&$ pagfis $=2311>$. Acesso em: 11/08/2020.

LYRA, Roberto. Um decênio de reformas penais. Revista Forense, Rio de Janeiro, Dez., 1940, p. 201.

MAGARINOS TORRES, Antonio Eugenio. Processo penal do juri no Brasil. Revista de Direito Penal, Rio de Janeiro, v. XX, fasc. II, a. V, jan./1938, p. 239-241.

MAGARINOS TORRES, Antonio Eugenio. Processo penal do juri no Brasil. Revista de Direito Penal, Rio de Janeiro, v. XXIV, fasc. II, a. VII, fev./1939.

MAGARINOS TORRES, Antonio Eugenio. O jury na commissão de Código de Processo Penal para o Brasil. Revista de Direito Penal, Rio de Janeiro, v. VIII, a. III, jan., 1935.

NOTA EDITORIAL. Projeto do Código do Processo Penal da República dos Estados Unidos do Brasil. Revista da Faculdade de Direito - Universidade de São Paulo, v. XXXIV, fasc. III, set.-dez./1938.

NOTAS E COMENTÁRIOS. O novo código de processo penal. Revista Forense: Rio de Janeiro, jan., 1942.

O CODIGO DOS INTERVENTORES. Republica. Florianópolis, p. 5.09 set. 1931. 
O NOVO CÓDIGO JUDICIARIO. República: Florianópolis, quinta-feira, $1^{\circ}$ de novembro de 1928, p. 2. Disponível em: <http://memoria.bn.br/DocReader/ DocReader.aspx?bib=711497x\&Pesq=\%22constituição\%20estadual\%22\&pagfis $=25942>$. Acesso em: 15 out. 2020

QUEIROZ, Narcélio de. O novo código de processo penal. Archivo Judiciário, Rio de Janeiro, 5 jan. 1943.

SANTA CATARINA. Lei ${ }^{\circ}$ n. 1526, de 14 de novembro de 1925. Codigo Judiciario do Estado de Santa Catarina. Florianópolis, SC: Officinas A Elect. da Imprensa Official, 1926.

SANTA CATARINA. Lei ${ }^{\circ}$ n. 1640, de 03 de novembro de 1928. Codigo Judiciario do Estado de Santa Catarina, 1928.

SANTA CATARINA. Decreto 157, de 19 de setembro de 1931. Codigo Judiciario do Estado de Santa Catarina. Florianópolis, SC, 1931.

SCHMIDT, Felippe. Mensagem apresentada ao Congresso Representativo. Em 11 de Agosto de 1900 pelo Dr. Felippe Schmidt, Governador do Estado. Disponível em: http://memoria.bn.br/DocReader/873438/135. Acesso em: 11/08/2020.

SILVA E OLIVEIRA, Antonio P. Mensagem apresentada ao Congresso Representativo, em 22 de julho de 1925, pelo Coronel Antonio Pereira da Silva e Oliveira, Vice-governador, no exercício do cargo de Governador do Estado de Santa Catharina. Disponível em: http://memoria.bn.br/DocReader/873438/2073. Acesso em: 12/08/2020.

WHITACKER, Firmino. Jury (Estado de S. Paulo). São Paulo: Typ. Espíndola, Siqueira \& Comp., 1904.

\section{Bibliografia}

Consciência Negra. Escola de Administração Universidade Federal da Bahia. Disponível em: http://www.adm.ufba.br/pt-br/noticia/consciencia-negra. Acesso em: 20/08/2020.

COSTA, Pietro. Di che cosa fa storia della giustizia? Qualche considerazione di método. In: LACCHÈ, Storia dell giustizia e storia del diritto: Prospetive europee di ricerca Luigi; MECCARELLI; Massimo (a cura di). Macerata: eum, 2012. p. 17-43.

COSTA, Pietro. Em busca de textos jurídicos: quais textos para qual historiador?. In: Id., Soberania, representação, democracia. Curitiba: Juruá, 2010.

Ernesto Carneiro Ribeiro. In.: Wikipedia enciclopedia digital. Disponível em: https://pt.wikipedia.org/wiki/Ernesto_Carneiro_Ribeiro. Acesso em: 20/08/2020. 
FLORES, Alfredo de Jesus Dal Molin; NODARI, Régis João. Entrelaçamentos Culturais na Primeira República: O código de processo penal dos Estado do Rio Grande do Sul (1898) e suas fontes doutrinárias e legislativas. Revista da Faculdade de Direito de Minas Gerais, Belo Horizonte, n. 74, p. 65-96, 2019.

NUNES, Diego. Codificação, Recodificação, Descodificação? Uma História das dimensões jurídicas da justiça no Brasil Imperial a partir do Código de Processo Criminal de 1832. Revista da Faculdade de Direito de Minas Gerais, Belo Horizonte, n. 74 , p. 135-166, 2019.

NUNES, Diego. O Percurso dos crimes políticos durante a Era Vargas (1935-1945): do direito penal político italiano ao direito da segurança nacional brasileiro. Dissertação (Mestrado em Direito) - Curso de Pós-Graduação em Direito, Universidade Federal de Santa Catarina, Florianópolis, 2010.

NUNES, Diego. Le "irrequietas leis de segurança nacional": sistema penale e repressione del dissenso politico nel Brasile dell'Estado Novo (1937-1945). Tese de Doutorado (Direito). Università degli studi di Macerata (Itália), 2014. Disponível em: <https://u-pad.unimc.it/retrieve/handle/11393/192670/2863/Diego\%20 Nunes\%20tesi\%20Leis\%20de\%20seguran\%C3\%A7a\%20nacional\%20UniMC. pdf>. Acesso em: 18 mar. 2020.

NUNES, Diego. Processo Legislativo para além do Parlamento em Estados Autoritários: uma análise comparada entre os Códigos Penais Italiano de 1930 e Brasileiro de 1940. Seqüência: Florianópolis, v. 37, n. 74, 2016.

SABADELL, A. L. Los Problemas del derecho procesal penal único en una federación: la experiencia de Brasil. In: Instituto Nacional de Ciencias Penales; Max-Planck Institut fuer Auslaendisches und Internationales Strafrecht (org.). Hacia la Unificación del Derecho Penal. Logros y desafíos de armonización y homologación en México y en el Mundo. Districto Federal- México: Instituto Nacional de ciencias Penales-INACIPE, 2006, v. 1, p. 585-615.

SILVEIRA, Mariana de Moraes. Revistas em tempos de reformas: Pensamento Jurídico, Legislação e Política nas Páginas dos Periódicos de Direito (1936-1943). Dissertação (Mestrado em História), Universidade Federal de Minas Gerais, Belo Horizonte, 2013.

SILVEIRA, Mariana de Moraes. Direito, ciência do social: o lugar dos juristas nos debates do Brasil dos anos 1930 e 1940. Estudos Históricos, Rio de Janeiro, vol. 29, no 58, p. 441-460, maio-agosto 2016.

SILVEIRA, Mariana de Moraes. Técnicos da legalidade: juristas e escrita das leis (Argentina e Brasil, primeira metade do século XX). Estudios Sociales Contemporáneos, v. 17, p. 86-102, 2017. 
SONTAG, Ricardo. "Código criminológico"? Ciência jurídica e codificação penal no Brasil 1888-1899. Rio de Janeiro: Revan, 2014.

SONTAG, Ricardo. "A eloqüência farfalhante da tribuna do júri”: o tribunal popular e a lei em Nelson Hungria. História [online]. 2009, vol.28, n.2, p. 267-302. VIEIRA, João Alfredo Medeiros. Notas para a história do poder judiciário em Santa Catarina. Florianópolis: Fundação Catarinense de Cultura, 1981.

\section{Informações adicionais e declarações dos autores}

Declaração de conflito de interesses (conflict of interest declaration): os autores confirmam que não há conflitos de interesse na realização das pesquisas expostas e na redação deste artigo.

Declaração de autoria e especificação das contribuições (declaration of authorship): todas e somente as pessoas que atendem os requisitos de autoria deste artigo estão listadas como autores; todos os coautores se responsabilizam integralmente por este trabalho em sua totalidade.

- Diego Nunes: projeto (conceptualization), desenvolvimento da metodologia (methodology), coleta e análise de dados (data curation), participação ativa nas discussões dos resultados (validation), revisão crítica com contribuições substanciais (writing - review and editing), aprovação da versão final.

- Bárbara Madruga da Cunha: projeto e esboço inicial (conceptualization), desenvolvimento da metodologia (methodology), coleta e análise de dados (data curation), levantamento bibliográfico (investigation), revisão bibliográfica (investigation), redação (writing - original draft), aprovação da versão final. 
- Mayessa H. Costa: projeto e esboço inicial (conceptualization), coleta e análise de dados (data curation), levantamento bibliográfico (investigation), revisão bibliográfica (investigation), redação (writing - original draft), aprovação da versão final.

Declaração de ineditismo e originalidade (declaration of originality): os autores asseguram que o texto aqui publicado não foi divulgado anteriormente em outro meio e que futura republicação somente se realizará com a indicação expressa da referência desta publicação original; também atestam que não há plágio de terceiros ou autoplágio.

Editorial process dates

(http://www.ibraspp.com.br/revista/index.php/RBDPP/about/editorialPolicies)

- Submission: 20/05/2021

Editorial team

- Desk review and plagiarism check: 01/06/2021

- Editor-in-chief: 1 (VGV)

- Review 1: 03/06/2021

- Associated-editor: 2 (RS e GM)

- Review 2: 17/06/2021

- Preliminary editorial decision: $19 / 06 / 2021$

- Reviewers: 2

- Correction round return: 07/07/2021

- Final editorial decision: 08/07/2021

\section{HOW TO CITE (ABNT BRAZIL):}

NUNES, Diego; CUNHA, Bárbara M.; COSTA, Mayessa H. O Processo Penal no estado de Santa Catarina entre Primeira República e Era Vargas. Revista Brasileira de Direito Processual Penal, vol. 7, n. 2, p. 1097-1140, mai./ago. 2021. https://doi.org/10.22197/rbdpp.v7i2.580

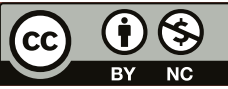

Esta obra está licenciada com uma Licença Creative Commons Atribuição-NãoComercial 4.0 Internacional. 